\title{
A CRENÇA NO PODER JURISDICIONAL DO ESTADO: JUDICIALIZAÇÃO \\ DAS RELAÇÕES SOCIAIS E POLITIZAÇÃO DO JUDICIÁRIO / BELIEF IN \\ THE STATE JUDICIAL POWER: JUDICIALIZATION OF SOCIAL RELATIONS AND POLITICIZATION OF THE JUDICIARY
}

João Batista Damasceno ${ }^{1}$

\begin{abstract}
Resumo
O objetivo do presente artigo é situar historicamente o significado da palavra "tolerância" na cultura ocidental. O artigo busca mostrar como correntes representativas do pensamento social moderno não consideram viável a concretização jurídica dessa virtude política nas democracias pluralistas.

Pretende ainda o artigo, discordando dessas correntes, investigar quais seriam as bases conceituais da nova tolerância, considerada como princípio social e político essencial para o funcionamento do Estado democrático de direito.
\end{abstract}

Palavras-chave: Tolerância. Cultura ocidental. Virtude. Estado democrático de direito.

\begin{abstract}
The purpose of this article is historically situate the meaning of the word "tolerance" in Western culture. The article seeks to show how representative tendencies of modern social thought does not consider viable legal embodiment of this political virtue in pluralistic democracies.

Still want the item, disagreeing with these currents, which would investigate the conceptual basis of the new tolerance, considered essential political and social principle for the functioning of the democratic state based on the rule of law.
\end{abstract}

\footnotetext{
${ }^{1}$ Doutor em Ciência Política pela Universidade Federal Fluminense - UFF. Mestre em Ciência Polícia pelo IFCS/UFRJ. Juiz de Direito do Tribunal de Justiça do Estado do Rio de Janeiro.
} 
Keywords: Tolerance. Western culture. Virtue. Democratic state based on the rule of law.

1. O Poder Judiciário e seu papel na República; 2. O Judiciário e o golpe militar de 1964: A trajetória para a acomodação; 3. Judicialização da Política e das Relações Sociais; 4. A Judicialização da Política: Apropriações, Usos e Conceitos; 5. A Judicialização da Política e Judicial Review; 6. Judicialização das Relações Sociais; 7. Casos de Judicialização de Relações sociais; 8. A expansão do Poder Judiciário e a Urbanização da População Brasileira; 9. Referências.

\section{O Poder Judiciário e seu papel na República}

A proclamação da república e o advento da Constituição de 1891, com rígida separação formal entre os poderes, não fez cessar a ingerência de interesses políticos nas nomeações, promoções e, sobretudo no funcionamento do Poder Judiciário. A separação formal dos poderes, na $1^{\text {a }}$ República (1889 - 1930), não significou que os poderes passassem a desempenhar cada qual a sua função, sem interferência no outro. Além disto, nem sempre o Poder Judiciário quis desempenhar os papéis institucionais que lhe estavam reservados. Em seus pareceres e petições Ruy Barbosa ${ }^{2}$, mais do que expor os argumentos em prol dos interesses que defendia, por vezes desenvolvia maiores argumentos para convencer o Supremo Tribunal Federal de que ele tinha poderes para apreciar certas questões, embora não os quisesse desempenhar.

Oliveira Vianna ${ }^{3}$ afirmou que as liberdades civis somente não naufragaram por completo, durante a primeira república, em decorrência da descentralização política operada, unicamente por causa da aplicação extensiva do habeas corpus, inspirada em Ruy Barbosa, pois a descentralização republicana, estadualizando a magistratura e

\footnotetext{
${ }^{2}$ Barbosa, Ruy. 1928.

${ }^{3}$ Vianna, Oliveira. 1949: 230/231
} 
fortalecendo os poderes das oligarquias representou indiscutivelmente um passo atrás, um verdadeiro regresso no sistema de garantia das liberdades privadas.

Foi pela ação de Ruy Barbosa que o habeas corpus, concebido para a defesa da liberdade de locomoção, converte-se em instrumento de proteção de qualquer direito ou interesse individual, violados ou ameaçados por violência ou coação. Do indivíduo contra qualquer ilegalidade. Mas, a reforma da Constituição em 1926 restringiu o habeas corpus exclusivamente à garantia da indevida "prisão ou constrangimento 302reque em as liberdade de locomoção." (Art. 72 § 22).

A idéia de que o Poder Judiciário brasileiro se fez poder político-institucional com a República foi contestada tanto por Victor Nunes Leal ${ }^{4}$ quanto por João Mangabeira ${ }^{5}$. Em contraposição, o Ministro Carlos Mário da Silva Velloso, na apresentação do livro de Lenine Nequete, argumenta no sentido de que o Poder Judiciário se transformara em efetivo poder do Estado com a república, o que encontra apoio no pensamento de Lenine Nequete, de Aliomar Baleeiro ${ }^{6}$ e no de Lêda Boechat Rodrigues.

Quanto à atuação específica do Supremo Tribunal Federal (STF) na primeira república há afirmações contraditórias. João Mangabeira afirmou que o STF foi o poder que "mais falhou" (Mangabeira, 1943: 186) na República, por haver deixado de cumprir o papel político-constitucional que lhe competia. Para ele, o STF avançou muito timidamente no sentido de exercer o seu papel. E, ainda assim, a partir da ação de Ruy Barbosa que fustigava seu funcionamento a exemplo dos julgados da Suprema Corte dos EUA. Mangabeira atribuiu a Ruy Barbosa a concepção de que o STF mudaria a República se houvesse nele uma maioria que exercesse as suas atribuições constitucionais.

A inexistência de controle de constitucionalidade das leis ou atos normativos inexistia no Império, isto porque "a sanção imperial expurgia-as de qualquer vicio" (Nequete, 2000d: 23). Desta forma, embora o Decreto 848 de 11 de outubro de 1890 que dispunha sobre esta possibilidade, pois assegurava que o poder de interpretar a lei envolve necessariamente o de verificar sua conformidade com a Constituição, o que foi objeto de expressa disposição na Constituição de 1891 (art. 59, 3, § 1 ', "a" e "b”) e

\footnotetext{
${ }^{4}$ Leal, Victor Nunes. Coronelismo, Enxada e Voto, 1997: 231

${ }_{6}^{5}$ Mangabeira, João. Rui, o estadista da República, 1943.

${ }^{6}$ Aliomar Baleeiro foi deputado udenista, participou da sessão do Congresso Nacional convocada em 01/04/1964, contra o disposto no regimento daquela instituição, e que resultou na ilegal declaração de vacância da presidência da república, quando se sabia, oficialmente, que o presidente da república se encontrava no território nacional. Foi posteriormente nomeado ministro do STF.
} 
posteriormente na Lei 221 de 1894, o Juiz Alcides Mendonça Lima, fora denunciado e condenado pelo Tribunal de Justiça do Estado do Rio Grande do Sul por haver, em 28 de março de 1896, declarado a inconstitucionalidade de lei estadual sancionada por Julio de Castilhos. O assunto foi objeto de controvérsia nos jornais e no meio jurídico, merecendo pareceres de Ruy Barbosa, M. ${ }^{a}$ Duarte de Azevedo, João Mendes de Almeida, Brasílio dos Santos, A.J. Pinto Ferraz, Pedro Lessa e Rafael Correia da Silva, todos no sentido da possibilidade de um juiz estadual reconhecer a inconstitucionalidade de lei estadual que contrariasse a Constituição da República.

Sobre o assunto, sem ainda estar familiarizado com o conceito de supremacia da Constituição - oriunda do poder constituinte - sobre o Estado e sobre os atos legislativos ou normativos editados pelos poderes constituídos, escreveu Machado de Assis em A Semana, no dia 05 de abril de 1896: "O que vagamente me parece, é que se o estatuto político do Estado difere em alguma parte do da União, é impertinência não cumprir o que os poderes do Estado mandam." (Assis, 1997: 18)

Da mesma forma o Desembargador Procurador-Geral que recebera ordens de Júlio Prates de Castilho para formular a acusação contra o juiz escreveu que "ousou o denunciado afrontar o regime constitucional do Estado e arvorar-se em supremo e original poder moderador”. (Nequete, 2000d: 24).

O juiz gaúcho foi condenado pelo Superior Tribunal de Justiça do Estado do Rio Grande do Sul (nome que fora dado ao tribunal daquele Estado) e recorreu para o STF, onde ante a argumentação de Ruy Barbosa foi a decisão reformada, ainda que timidamente e sem adentrar na questão da inconsticionalidade do dispositivo da Constituição Gaúcho em face da Constituição da República.

Os juízes, quando não integrantes do quadro da oligarquia, estavam sujeitos à sedução ou à vingança pelo poder local "foram, aliás, muito variados os meios postos em prática pelos governos estaduais para submeter a magistratura, como a disponibilidade, a alteração de limites ou a supressão de circunscrições judiciárias, a retenção de vencimento etc" (Leal, 1997: 228).

Diversamente, os juízes federais e o STF se revelavam importantes instituições nas relações políticas durante a vigência da política dos governadores. Os juízes seccionais eram nomeados pelo Presidente da República dentre candidatos indicados pelas oligarquias dominantes nos Estados e os Ministros do Supremo Tribunal Federal dentre auxiliares seus ou membros do seu partido ou grupo político. 
A indicação e controle sobre os juízes seccionais era de profunda relevância para manutenção do poder da oligarquia estadual ou para afastamento dela. Enquanto reinou a Política dos Governadores, o descumprimento de uma decisão do juiz seccional era motivo para intervenção federal no Estado (art.6 $6^{\circ}, 4$ da Constituição de 1891). Além disto o juiz seccional tinha atribuições constitucionais para julgar os conflitos entre a União e os Estados e os crimes políticos.

Nos momentos de maior estabilização das instituições diminui a pressão política sobre o judiciário e até se reforça seu papel de intérprete da lei e da Constituição. Já no Império se encontra em carta dirigida pelo Conselheiro Saraiva a Nabuco de Araújo defesa da "supervisão das eleições por um Poder Judicial constitucional $e$ independente, para punir a fraude e o abuso de autoridade" (Nabuco de Araújo apud Koerner, 1998: 91).

A intervenção dos magistrados para solução dos conflitos políticos era defendida com o fim de que exercessem a função de árbitros da política, tal como exerciam a função de árbitros dos conflitos civis. No entanto, a partidarização do judiciário na primeira república levou ao temor de sua politização e a Constituição de 1934 em seu art. 68 dispunha que era "vedado ao Poder Judiciário conhecer de questões exclusivamente políticas. " Idêntica disposição era contida no art. 94 da Carta de 1937.

Pela lei 3139 de 02 de agosto de 1916, conhecida como lei Bueno de Paiva, foi reconhecida a competência dos Estados para a qualificação dos eleitores e a regulamentação das eleições estaduais e municipais e foi confiada a qualificação para as eleições federais exclusivamente às autoridades judiciárias. A lei satisfazia as potestades locais, ao manter no âmbito local a qualificação dos eleitores para as eleições estaduais e municipais e atribuía à autoridade judiciária a qualificação para as eleições federais, com possibilidade de recurso para uma junta formada por uma junta estadual.

Se na primeira república a nomeação do juiz seccional era cobiçada para fins de controle da máquina estadual ou tomada das mãos da oligarquia oposicionista, com o advento da criação da Justiça Eleitoral pelo Decreto 21.076 de 24/02/1932 e edição da Constituição de 1934 se pretendeu a despolitização de tais funções. "Na cúpula do sistema estava o Superior Tribunal Eleitoral, que decidia as dúvidas e impugnações em estilo judiciário, isto é, pelo alegado e provado e, segundo consta, sem interferência da atividade partidária” (Leal, 1997: 268).

Assim, dispunha a Constituição de 1934 em seu art. 82, § 20 "a" e "b" que o Tribunal Superior e Tribunais Regionais da Justiça Eleitoral seriam compostos, 
paritariamente, por membros sorteados, respectivamente, da Corte Suprema e desembargadores do Distrito Federal, além de uma terça parte indicada pelo Presidente da República.

O sorteio dos membros dos Ministros e dos Desembargadores do Distrito Federal para o Tribunal Superior e dos Desembargadores e Juízes para os Tribunais Regionais era medida que visava a eliminação de critério político para a escolha feita internamente nos tribunais, a exemplo do critério utilizado quando a escolha do juiz seccional era feita pelo Presidente da República. Por outro lado, a impossibilidade de recusa do sorteado impedia a fraude no processo de escolha e renúncia visando fazer cair sobre outro a escolha.

A Constituição de 1934, embora trazendo pela primeira vez para a ordem constitucional a possibilidade de intervenção do Estado na ordem econômica e social, continha expresso dispositivo (art. 68) vedando ao Poder Judiciário "conhecer de questões exclusivamente políticas”. Tal dispositivo é mantido na Constituição de 1937 (art. 94).

Ao passo que o Estado ampliava sua base de atuação, se permitindo intervir na ordem econômica e social, promovia tensão entre os poderes ao trazer dispositivo que excluía da apreciação pelo Poder Judiciário questões que não fossem jurídicas, sem distinguir o que era causa política ou jurídica. Jamais se admitia aos juízes considerações de ordem política e portanto de juízos de conveniência e oportunidade, próprios das decisões políticas.

O que os textos constitucionais de 1934 e 1937 buscavam era reduzir a ação do juiz partidário cuja atuação se dava com fundamento em juízo de conveniência e oportunidade, por meio de conceitos indeterminados como "interesse público" e "ordem social” ou razões de ordem pessoal, visando a contemplar interesses locais ou de grupos nos quais estivesse incluído ou disposto a satisfazer. Por outro lado, se buscava reduzir os poderes do judiciário e evitar que se imiscuísse nas questões da nova ordem que se instituía. A ordem constitucional de 1934 e 1937 impunha ao judiciário fundar suas decisões, exclusivamente, na ordem jurídica.

A impossibilidade de apreciação de casos de natureza política já havia sido objeto de inúmeros trabalhos de Ruy Barbosa, que reconhecendo esta impossibilidade do Poder Judiciário, cujo modo de atuação há que se fundar na legalidade, ao mesmo tempo afirmava não se poder apresentar "objeção do caso político" se a matéria tiver sendo tratada sob o ângulo da legalidade. 
$\mathrm{O}$ caso político, no que contém juízo político, portanto, de conveniência e oportunidade, está imune à apreciação do Poder Judiciário. Mas, sua legalidade pode ser verificada pelo judiciário (Barbosa, 1928: 284).

Tanto a Constituição de 1934 quanto a de 1937 buscou reduzir a discricionariedade dos membros do Poder Judiciário para formular julgamentos fundamentos em razões distintas das enunciadas legalmente, fundados $\mathrm{em}$ discricionariedade ou por interesses políticos ou pessoais, bem como instituiu o reconhecimento de competência para os casos submetidos sob a forma jurídica, mesmo que de interesse político. Foi a Constituição de 1934 que inaugurou a regra da competência dos tribunais na elaboração de seus regimentos internos, o que foi mantido na Carta de 1937, e que implicou em atribuição de atividade legislativa aos tribunais.

A concepção de que a centralização política do Estado, durante a vigência da Carta de 1937, e a racionalização dos procedimentos implicou num esvaziamento do poder local e se verifica porque "na medida em que aumenta a eficácia do mecanismo judiciário e policial dos Estados, mais subordinada ao poder se torna essa magistratura oficiosa." (Leal, 1997: 242). Victor Nunes Leal observa que fazia parte do compromisso "coronelista", o conformismo político que possibilitava a nomeação dos delegados e subdelegados e mesmo a ligação com a justiça e a promiscuidade dos interesses locais com as razões de decidir dos órgãos judiciários. Dentre as muitas medidas que se buscou para a centralização do Estado e esvaziamento dos poderes das unidades federativas e dos chefes locais, uma é sobremaneira relevante para o funcionamento do Poder Judiciário, trata-se da uniformização da lei processual, ou seja, a adoção de um Código de Processo Federal, para todo o país, pondo fím aos regionalismos processuais e suas peculiaridades.

Os Estados continuaram detentores do poder de organização e divisão judiciária, mas a edição de lei processual passou a ser exclusiva da União. Por organização se compreende a Constituição dos órgãos judiciários, a enumeração e nomenclatura dos juízes e tribunais, suas composições e competências, ou seja: a estruturação dos órgãos judiciários e divisão de funções entre os mesmos.

As ligações dos juízes com os chefes locais podiam diminuir na medida em que eram ampliadas as garantias do Poder Judiciário. O art. 177 da Constituição de 1937 possibilitava que os membros da magistratura pudessem ser aposentados compulsoriamente, subtraindo na prática todos as garantias estabelecidas na Constituição. 
Tratando das garantias da magistratura nos regimes autoritários, Oliveira Vianna $^{7}$, em parecer, sobre o sentido e alcance do art. 177 da Constituição de 1937 defendia que os juízes que adotassem posições diferentes das do regime deveriam ser aposentados compulsoriamente, porque não lhes era lícito pensar fora dos parâmetros oficiais (pensamento totalitário), cuja vontade da nação estava encarnada na vontade do chefe do Estado.

Mas, dizia que os juízes que fossem mantidos em atividade não poderiam ser molestados em sua independência. Salienta que se os funcionários administrativos estão sujeitos à obediência ao chefe do Estado, os magistrados não podem estar, sob pena de violação ao princípio da independência dos juízes, indispensável ao exercício de suas funções, mesmo que não se esteja num regime de separação de poderes ${ }^{8}$. Dissse ainda que nem nos regimes totalitários de então estavam os juízes sujeitos à disciplina e hierarquia administrativa, bem como controlados no exercício de suas funções, embora tão tivessem a independência própria dos regimes pluralistas, assecuratórios de direitos subjetivos individuais e garantidos pelo sistema da separação de poderes. Sobre os juízes, disse Oliveira Vianna que não estavam

A redação originária do art. 177 da Constituição de 1937, analisada por Oliveira Vianna, atribuía ao Presidente da República poderes para durante 6 meses decretar tal aposentação. Mas, a Lei Constitucional 2, de 24 de maio de 1938, transformou este prazo em tempo indeterminado. Assim, os juízes estaduais, uma vez que a justiça federal de primeira instância havia sido abolida, estavam sujeitos à permanência no cargo por juízo de conveniência e oportunidade dos governantes estaduais, que podiam igualmente lhes afastar imotivadamente. No entanto, o Decreto Lei 1202 de 8 de abril de 1939, submeteu a aposentadoria dos juízes estaduais, antes de competência exclusiva dos governantes estaduais, a prévia autorização do Presidente da República.

A necessidade de prévia autorização do Presidente da República para o afastamento dos juízes não significou maior independência do judiciário em relação ao mando local. Isto porque em sendo os governos estaduais, durante o Estado Novo, submetidos à nomeação do Presidente da República, não tinham independência para pronunciar julgamentos que pudessem ir de encontro aos interesses políticos reinantes, fossem do Estado ou dos governantes.

\footnotetext{
${ }^{7}$ Vianna, 1991: 177

${ }^{8}$ Vianna, 1991: 178
} 
Mas, a irregularidade do funcionamento institucional nem sempre decorreu da falta de garantias à magistratura. Mesmo quando detentores de independência funcional, nem sempre os juízes se afastaram dos interesses menos escrupulosos das situações políticas locais. "As garantias legais nem sempre podem suplantar as fraquezas humanas: transferência para lugares mais confortáveis, acesso aos graus superiores, colocação de parentes, gosto do prestígio, eis os principais fatores de predisposição política de muitos juizes." (Leal, 1997: 243)

A formação dos juízes associada ao papel desempenhado pela magistratura, na República Velha, tornava-se cada vez mais incompatível com a nova ordem de 1930 que, impulsionada pelas transformações políticas-econômicas em curso, ia se estruturando. $\mathrm{O}$ resultado eram conflitos entre a situação anterior e a que ganhava nova forma. Os conflitos eram quase sempre resolvidos com o afastamento de juízes de suas funções por consideração de "imperiosas razões de ordem pública" ou de "outra natureza relevante" (Nequete, 2000d: 67). Neste cenário, "Não instituiu, a Constituição de 1934, ao contrário do que fora de esperar, a Justiça do Trabalho como órgão do Poder Judiciário." (Nequete, 2000d: 78)

Assim não se depreendeu relevante tensão entre o Poder Executivo e o Judiciário nos anos 30-45. Restabelecida a ordem constitucional pela Constituição de 1934, o judiciário já se encontrava domesticado. Durante o Estado Novo foi estabelecido que os crimes cometidos contra a segurança do Estado e a estrutura as instituições ficariam sujeitos a uma justiça especial, conforme preceituava o art. 172 da Constituição de 1937, regulamentado pela lei 88 de 20 de dezembro de 1937. Mas, o Tribunal de Segurança Nacional, já se encontrava criado desde 1936 pela Lei 244 de 11 de setembro de 1936, cuja constitucionalidade o Supremo Tribunal Federal reconhecera em julgamento proferido em 11 de janeiro de 1937 ao negar habeas corpus impetrado por João Mangabeira ${ }^{9}$.

Mas, bastou que o Executivo começasse a fraquejar para que o judiciário, em arroubo de independência, se expusesse. Assim, em 11 de abril de $1945^{10}$ " permitiu-se insurgir - através da concessão de habeas corpus - contra alguma das condenações do Tribunal de Segurança: sobretudo quando a ditadura já começava a dar mostras de

\footnotetext{
${ }^{9}$ Nequete, Lenine. O Poder Judiciário no Brasil a partir da independência, 2000d: 85.

${ }^{10}$ Nequete, Lenine. O Poder Judiciário no Brasil a partir da independência, 2000d: 85.
} 
estar próximo o seu fim." (Nequete, 2000d: 85). O fato foi tratado em editorial do influente Jornal do Comércio de 12/04/1945 ${ }^{11}$.

A promulgação da Constituição de 1946 restabeleceu a feição do judiciário que havia sido instituído pela Carta de 1934, sem grandes alterações, salvo quanto à integração da Justiça do Trabalho na estrutura do Poder Judiciário. Igualmente não restaurou a Justiça Federal de primeira instância, embora tenha instituído o Tribunal Federal de Recursos para apreciação dos recursos nas causas de interesse da União Federal. Se o desequilíbrio das forças políticas que atuaram no período de 1946 a 1964 era evidente, com reiteradas tentativas de golpes, no âmbito do Poder Judiciário, tais tensões não se verificaram. O Poder Judiciário se manteve numa postura predominantemente de autonomia e independência. Entretanto, a política não revelava acentuado grau de judicialização, as relações sociais não se apresentavam judicializadas, nem havia direitos e conflitos sociais a serem dirimidos por ele. Por outro lado, sua autonomia não se revelava tão intensa a ponto de se apresentar como um "grupo inteiramente fechado". O árbitro das disputas políticas eram os militares. Estes se encontravam fortalecidos com a campanha na Europa, que resultou no vencimento do nazismo e do fascismo. Tendo em vista a situação dada, o Poder Judiciário atravessou o período 1945 e 1964 sem maiores tensões. Estas somente voltariam a se manifestar, e com intensidade, após os acontecimentos do $1^{\text {o }}$ de abril de 1964.

\section{O Judiciário e o golpe militar de 1964: A trajetória para a acomodação}

O golpe militar de 1964 propiciou vários momentos de tensão entre o judiciário e os chefes militares. Mas os conflitos ocorridos eram debitados, desde os primeiros momentos que se seguiram ao golpe e pelos que ascenderam com ele, aos perfis psicológicos dos personagens envolvidos, numa nítida tentativa de minimizar a gravidade do conflito institucional que se instaurara. Por exemplo, Aliomar Baleeiro, deputado udenista diretamente envolvido nos fatos que culminaram na ilegal declaração de vacância da presidência da república na sessão do Congresso Nacional, presidida pelo Deputado Auro de Moura Andrade, do dia 01 de abril de 1964 e que se tornaria

\footnotetext{
${ }^{11}$ Jornal do Comércio, 12/04/1945.
} 
ministro do Supremo Tribunal Federal por força de vaga decorrente do AI-2 editado em 27 de outubro de 1965, disse que "Conflitos entre o Executivo e o Judiciário, nos primeiros anos da Revolução de 1964, creio que não houve." (Baleeiro apud Vale, 1976:179)

Aliomar Baleeiro suaviza o conflito que se estabelecia entre a "linha dura" das forças armadas, alçadas ao poder por força do golpe de militar de 1964, e as instituições judiciárias no Brasil. Apesar de político, Baleeiro, nesta e em outras declarações, tenta subtrair a dimensão política e ideológica das tensões havidas entre instituições e grupos de interesses e as releva a conflitos pessoais ou casualidades.

O AI-2, de 27 de outubro, elevou de 11 para 16 o número dc ministros do STF, possibilitando ao executivo nomear 4 ministros. Com a edição do AI-5 foram cassados 3 ministros e 2 se aposentaram em repúdio à intervenção no STF. O numero de ministros do STF voltou a 11, mas o governo já tinha assegurado um judiciário domado na sua cúpula, o que viria a se expressar nas suas bases.

Com a edição do AI-2 foi restabelecida a justiça federal de primeira instância. Seus membros seriam nomeados pela Presidência da República. Não se cogitou de realização de concurso para provimento dos cargos.

Mesmo com a promulgação da Constituição de 1967, em 24 de janeiro daquele ano, o Presidente da República insistia no exercício do poder de nomear juízes federais, para julgar causas de interesse da União, sem concurso público, tal como o fazia no período dito discricionário até aquela promulgação, sobretudo sob os auspícios do AI-2 de 1965. Tais insistências em nomear juízes federais, sem concurso, mereceram estudo crítico de Victor Nunes Leal alusivo ao fim dos poderes do Presidente da República para tal, ante a edição da Constituição promulgada que inovava a ordem constitucional e não recepcionava aquele diploma da ditadura como legal.

Em 13 de dezembro de 1968 é editado o AI-5, suspendendo todas as garantias ainda remanescentes e possibilidade de pronunciamentos judiciais. Em 16 de janeiro de 1969 são aposentados compulsoriamente os ministros Victor Nunes Leal, Hermes Lima e Evandro Lins e Silva. O AI-6, de $1^{\text {o }}$ de fevereiro de 1969, retornou os números de ministros do STF para 11 e dispôs sobre a possibilidade de civis serem julgados pelos tribunais militares. Em 17 de outubro de 1969 é outorgada, pelos três Ministros militares, a emenda Constitucional $\mathrm{n}^{0}$ 1/69 que deu nova e integral redação à Constituição. "Desde então, sobretudo com a edição dos Atos ns. 5 e 6, cessaram os conflitos, e o Poder Executivo-Revolucionário passou a ter no Supremo um órgão 
administrativamente saudável, tecnicamente ágil (...), mas politicamente morto." (Vale, 1976: 166)

Domado ou cooptado ${ }^{12}$, atravessou o judiciário os anos de chumbo, notadamente, de 1969 a 1974, quando em 1974 o Ministro Eloy da Rocha, empossado em uma das vagas decorrentes do AI-2, proferiu diante do Presidente da República Ernesto Geisel discurso no qual dizia "da impossibilidade da vida judiciária pelo excesso de processos, e de outras causas, acarretando a crise do judiciário". (Nequete, 1975: 103) O General-Presidente encarregou-se de produzir estudo de tal crise e formulação de soluções.

Em abril de 1977 o Congresso Nacional foi fechado pelo General-Presidente da República a pretexto de se decretar a Reforma do Judiciário, o que o fez através da Emenda Constitucional $n^{0} 7$ de 13 de abril daquele ano. Hugo de Abreu, general Chefe do Gabinete Militar disse que "Na reunião do Conselho de Segurança Nacional, então convocado para dar parecer sobre a decretação do recesso do Congresso, o Presidente justificou a medida com a necessidade de aprovação da Reforma do Judiciário.”. (Abreu, 1979: 70)

A emenda constitucional $\mathrm{n}^{\mathrm{o}} 7$ estabeleceu a avocatória, possibilitando ao STF dispor em seu regimento sobre a avocação de causas processadas perante quaisquer juízos ou tribunais. A avocatória podia ser exercitada quando houvesse imediato perigo de grave lesão à ordem, à saúde, à segurança ou às finanças públicas, o que não tardou em ser incluído no regimento interno daquele Corte e nele permaneceu ${ }^{13}$ até não mais ser recepcionado pela Constituição de 1988. Igualmente impôs a edição de uma Lei Orgânica da Magistratura Nacional (Loman), o que veio a ser feito pela edição da Lei Complementar $35 / 79^{14}$, que se mantém quase integralmente em vigor, com exceção de poucas alterações, sobretudo pela LC 37/79. A Loman dispôs rigidamente sobre a substituição nos Tribunais, o que jamais foi implementado, numa flagrante ilegalidade pelos tribunais. Impôs a garantia de vitaliciedade dos juízes de primeira instância somente após o segundo ano de exercício da judicatura e determinou a criação de órgãos especiais nos Tribunais de Justiça com mais de 25 desembargadores, com atribuições administrativas e jurisdicionais da competência do tribunal pleno.

\footnotetext{
${ }^{12}$ Salete Maccalóz afirma que a maior parte da magistratura, principalmente dos Tribunais Superiores e Tribunais de Justiça, logo se aliou ao regime, como estreitos colaboradores (Ver: Maccalóz, Salete, 2002:13).

${ }_{14}^{13}$ Ver art. 254, III do RISTF (Brasil, legislação, RISTF).

${ }^{14}$ A Loman (Lei Orgânica da Magistratura Nacional), LC 35/79, ainda está em vigor.
} 
Se a justiça de primeira instância, ou magistratura de carreira se revela independente e profissional, nos tribunais locais se evidencia grande teor de politização ditada pelas relações com os interesses locais. Os tribunais regionais, sobretudo os estaduais, são expressão da concentração do poder local. Neste sentido o Órgão Especial, de criação pela EC 07/77, outorgada pelo "pacote de abril", é o extrato da concentração do poder no tribunal local. É efetivamente o órgão dos tribunais estaduais e regionais que detêm o poder no âmbito da respectiva justiça. Ao Órgão Especial dos tribunais compete decidir sobre promoções, remoções e julgamento dos juízes a eles vinculados.

Estas foram as linhas mestras resultantes do Pacote de Abril (EC 7/77): Avocatória, instituição de Órgão Especial nos Tribunais de Justiça e vitaliciamento dos juízes de primeira instância somente após o exercício por 2 anos.

A promulgação da Constituição de 1988 não alterou o formato deixado pelo “Pacote de Abril”. Na Constituinte de 1987-1988 prevaleceu a visão da cúpula do Poder Judiciário quanto ao seu modo de organização e funcionamento, tendo sido retirado do STF tão somente a possibilidade de avocar causas ainda submetidas a apreciação pelas instâncias inferiores. A cúpula de então era aquela constituída durante os governos militares, sendo o Presidente do STF, que presidira a instalação da Assembléia Nacional Constituinte, Ministro José Carlos Moreira Alves, tendo sido Procurador-Geral da República no período de 24 de abril de 1972 a 24 de abril de 1975 e nomeado para o STF pelo General-Presidente Ernesto Geisel em 18 de junho de $1975^{15}$.

Conforme observamos inicialmente o propósito das presentes considerações foi estudar/investigar o grau de discricionariedade e arbítrio das decisões judiciais, bem como as relações que possibilitam a reprodução dos grupos dominantes ou elite do Poder Judiciário. Ante a ampliação da competência do Poder Judiciário, que nos remete ao controle de constitucionalidade das leis e com a possibilidade de declaração de sua invalidade por incompatibilidade com a Constituição, nos remete ao case Marbury versus Madison, e se estende ao poder normativo dos tribunais, à autonomia para se autogerirem administrativa e financeiramente, com alocação de recursos e tomadas de importantes decisões administrativas, nem sempre sujeitas a controle ou, por vezes, sujeitas a controle pelas próprias autoridades exercentes de tais poderes ou, ainda, com controle por autoridades a elas sujeitas.

\footnotetext{
${ }^{15}$ Informação obtida no site http://www.stf.jus.br/portal/ministro/verMinistro.asp?periodo=stf\&id=10 em 03/01/2010 às 22:35h.
} 
Ao lado desta ampliação, operada no Brasil ao longo do século $\mathrm{XX}$, temos a centralização política e os mecanismos disciplinares e coercitivos, controladores da magistratura de primeira instância, instituídos pelo "pacote de abril" em 1977 e mantidos pela Constituição de 1988.

A compreensão destes processos demanda a compreensão da judicialização da política, a judicialização das relações sociais, a definição do papel do judiciário no nosso sistema, para o que é importante a compreensão dos mecanismos de ingresso nos cargos nos tribunais e ascensão funcional por promoção dos magistrados de $1^{\circ}$ grau.

\section{Judicialização da Política e das Relações Sociais}

Foi com o fim do ciclo dos governos militares (1964 - 1985), a gradual volta ao Estado de Direito e, mormente, a partir da promulgação e edição da Constituição de 1988 que o Judiciário adquiriu maior visibilidade social enquanto Poder da República. Desde esta ocasião, o Judiciário - por seu papel de instância decisória de demandas de natureza política $^{16}$ - vem sendo citado com 313requente313 nos noticiários da mídia. Salete Maccalóz salienta que anteriormente ao golpe militar de 1964 os juízes não tinham visibilidade nos meios de comunicação de massa e estabelece um momento em que um único juiz tinha visibilidade, mas ainda não era o judiciário.

Mas, a mídia e a sociedade descobriram o judiciário não só como mediador na solução de conflito de interesses, mas igualmente como objeto de notícia e de especulação ou ainda pelas qualidades que identificam seus integrantes como pessoas capazes dos mesmos gostos e preferências das demais.

$\mathrm{Na}$ nova realidade posta em curso nos dois últimos decênios do século $\mathrm{XX}$ a judicialização da política passou a ser acontecimento notório e, por essa razão, cada vez mais estudado pelas ciências sociais ${ }^{17}$. Necessário ainda acrescer, no que tange

\footnotetext{
${ }^{16}$ Dentre os muitos casos de natureza política que levou a sociedade à busca do Poder Judiciário para litigar contra os poderes constituídos se encontram os planos econômicos sucessivamente editados a partir de meados dos anos 80 e até o anos 90, dentre os quais o "Plano Collor", que consistia de um pacote econômico que bloqueou por 18 meses os saldos em contas correntes e aplicações financeiras, tabelou preços e pré-fixou salários. Instituído pela Medida Provisória no 168, de 15.03.1990, com vigência a partir do dia seguinte, foi convertida na Lei 8.024, de 12.04.1990, e teve sua duvidosa constitucionalidade mantida pelos tribunais superiores.

17 Obra publicada em 1997 de autoria de José Ribas Vieira, Maria Guadalupe Piragibe da Fonseca e Eliane Botelho Junqueira, e que publicizou pesquisa orientada pelos dois primeiros, trouxe referência à esta busca de conhecimento do Poder Judiciário, sobretudo a partir dos anos 90. "Os anos 90 vêm sendo
} 
especificamente a Ciência Política, que entre os poderes do Estado, no Brasil, o que tem sido menos visitado por profissionais desta área é o Poder Judiciário ${ }^{18}$. Tal questão se torna evidente com base em consulta a literatura especializada. Inclusive, julgamos correto considerar que muitos dos trabalhos sobre o Poder Judiciário que realizados por cientistas políticos, melhor se enquadram como trabalhos no campo da sociologia ${ }^{19}$, uma vez que mais voltados para o estudo das relações sociais que para relações de poder, propriamente ditas.

No caso, importante levar em conta que o Judiciário, no Brasil, a exemplo de poucos países no mundo, dentre os quais os Estados Unidos, conforme registra Lincoln Magalhães da Rocha (Rocha, 1990), é um Poder e, como tal, deve ser objeto da análise. Não basta basta estudar o Judiciário sob prisma sociológico ou jurídico, mas é necessário que a Ciência Política o estude enquanto Poder, atento às suas peculiaridades.

No exercício de funções governamentais, nos Estados ocidentais contemporâneos, os sistemas de governo são modos de relação entre o Poder Legislativo e o Poder Executivo. O modo como se estabelece este relacionamento, seja com a preponderância de maior independência entre eles ou maior colaboração, ou a combinação de ambos numa 314requente314, propicia a formação dos sistemas básicos de governos legítimos, quais sejam, presidencialismo, parlamentarismo ou convenção (Silva, 1991). E, o presidencialismo com o sistema de separação de poderes, na forma como foi concebido originalmente nos Estados Unidos, atribuiu dimensão política ao judiciário, quando lhe incumbiu de aplicar as leis, com precedência das hierarquicamente superiores.

Comumente, quando algum estudioso evoca os países europeus para tratar do "princípio da divisão de poderes de Montesquieu"20 tem como paradigma modelos

marcados por esforço positivo de desenvolvimento de investigações científicas sobre o Poder Judiciário no Brasil, principalmente através das pesquisas realizadas pelo Instituto de Estudos da Religião (ISER), pelo Instituto Direito e Sociedade (IDES), pelo Instituto de Estudos Econômicos e Políticos de São Paulo (IDESP) e pelo Instituto Universitário de Pesquisas do Rio de Janeiro (IUPERJ) que contribuíram para um melhor conhecimento do Judiciário e de seus atores." (Junqueira et. al., 1997: 15)

${ }^{18}$ Castro, Marcus Faro. O Supremo Tribunal Federal e a Judicialização da Política in Revista Brasileira de Ciências Sociais, vol 12, 1997 diz que: "O funcionamento das cortes judiciais e seu papel na democracia têm sido pouco estudados pela Ciência Política brasileira."

${ }^{19}$ A doutoranda em Sociologia Gisele Silva Araújo em artigo apresentado no VIII Congresso Luso-AfroBrasileiro de Ciências Sociais diz que a "Os fenômenos da juridificação das relações sociais e a judicialização da política tem sido objeto freqüente das Ciências Sociais dos últimos anos."

${ }^{20}$ Montesquieu, tido como fundador da concepção da separação dos poderes em O Espírito das Leis, reduzia o Poder Judiciário a um poder neutro ou "na boca da lei", sem lhe reservar o poder de desconstituir atos do legislativo. 
parlamentares nos quais a independência e a autonomia dos poderes não se revelam com nitidez. Se tal inexistência de limites nítidos entre a atividade executiva e parlamentar dos estados europeus não são percebidas, com muito mais razão também não são as atividades judiciais. Entretanto, a questão tem ampla visibilidade no Brasil. Em estudos recentes o Judiciário aparece configurado, em sua atuação, como um dos poderes do Estado. Vale observar que a concepção de Montesquieu foi elaborada em plena vigência do absolutismo e postula a proteção de liberdades individuais contra os abusos do governo, correspondendo a uma atuação estatal voltada para a consecução de ideais liberais. Assim, a tripartição dos poderes, concebida por Montesquieu, visava preservar os princípios da segurança jurídica e da unidade na aplicação do direito, limitando a atuação judicial.

O modelo adotado no Brasil é o modelo norte-americano do Estado constitucional com a separação dos poderes, o que propicia a verificação de compatibilidade da lei e dos atos normativos, editados pelo Poder Legislativo, a que se dá o nome de controle de constitucionalidade difuso ou concentrado. Observe-se ainda que para ao autor de $O$ Espírito das Leis ${ }^{21}$ o Poder Judiciário não passava de um mero executor de leis.

Ao tempo que concebera o seu tipo de Estado, Montesquieu não previa uma atuação estatal voltada a garantir o bem-estar dos cidadãos e muito menos a figura de um Estado prestador de serviços públicos, assim definidos de acordo com as suas leis. $\mathrm{Na}$ moldura clássica da tripartição dos poderes o Estado não estava concebido como orientador de transformações sociais, que ficaram a cargo da autocomposição da sociedade. Este modelo, em termos econômicos, se afigurava garantidor da efetivação do sistema de livres trocas e livre mercado. Mas, o papel do Judiciário e dos juízes no nosso sistema pouco se refere ao que fora concebido por Montesquieu, seja em razão da adoção do modelo que construímos, seja pelas transformações sociais ocorridas no século XIX e XX, fenômenos que alteraram qualitativamente o papel do Estado e de suas instituições.

Assim, a concepção de separação de poderes consagrada por Montesquieu, já não pode ser evocada para explicar a separação de poderes que vivenciamos na atualidade. Isto porque as transformações políticas e sociais acabaram por alterar profundamente as estruturas do Estado, atribuindo-lhe não só a defesa da liberdade individual, como concebida no Estado Moderno, mas a realização do Estado como um

${ }^{21}$ Montesquieu, 1993: 179

Revista Quaestio Iuris, vol.05, nº1. ISSN $1516-0351$ p. 300-341 
promotor ativo de mudanças sociais. O "Estado do Bem-Estar Social" "22, que veio a baila após a $2^{a}$ guerra mundial (1939 - 1945), embora remonte à Constituição Alemã de Weimar e tenha sido adotado entre nós pela Constituição de 1934, acabou representando um momento significativo da absorção do conceito de Justiça pelo Direito. Desse modo, o direito passa a não mais configurar mera técnica de controle social, mas sim instrumento válido de consecução de justiça.

Os ideais de justiça social e justiça distributiva pelo Direito resulta na expansão da atividade estatal a fim de 316requen-los e na intervenção no domínio econômico e na propriedade privada com o fim de garantir aos cidadãos uma justa parte da riqueza socialmente produzida, através de serviços estatais. Diversamente no Estado liberal, a intervenção do Estado na propriedade privada somente se poderia fazer mediante modalidade sancionatória para punir pelo desatendimento a um comando do Estado, por meio de multas ou outros meios punitivos.

Araújo (2004: 1) afirma que a explosão legal que se realçou nas últimas décadas é decorrente do Estado do Bem-Estar Social que teria lançado mão do Direito para instrumentalizar as políticas sociais. O Estado do Bem-Estar Social Contemporâneo de Direito transforma em norma jurídica suas decisões políticas e essas normas são projetivas, portando voltadas para o futuro, mergulhando o Direito no campo da incerteza e da circunstancialidade. O Poder Judiciário passa então a ser incitado a decidir sobre matérias com as quais não teria contato, se restrito à concepção tradicional de separação dos poderes. A judicialização leva, em suma, o judiciário a ter uma atuação interpretativa do texto legal, legislando implicitamente, mas positivamente, ao 316reque-lo.

Na nova situação dada, o processo de interpretação de qualquer texto legal passa a ser atividade voltada para o futuro. Portanto, projetiva, assumindo o juiz, em suas decisões, o papel político de concretizar programas constitucionais ou normas programaticamente dispostas na Constituição e de implementação atribuída ao legislador ou ao administrador. Acresça-se a isto, a extensão de textos constitucionais como o da Carta de 1988 que chegou a um nível de especificidade jamais visto em quaisquer das nossas constituições anteriores, sobretudo no elenco dos direitos sociais e

\footnotetext{
${ }^{22} \mathrm{O}$ Welfare state ou Estado do Bem Estar Social é o produto dos movimentos operários, de uma crise do liberalismo e de um pacto social-democrata ocorridos no inicio do século XX. As prestações estatais do Estado do Bem Estar Social se refletem por um lado em leis que sustentam o capitalismo organizado pelo Estado ante a crise econômica do Estado liberal e por outro lado a assunção de papéis ante o reequilíbrio jurídico das desigualdades sociais.
} 
no balizamento da atuação sócio-econômica dos agentes públicos, conferindo ao Poder Judiciário competência para julgar, segundo os preceitos constitucionais de justiça social, razoabilidade e oportunidade da atuação governamental.

No citado parecer sobre o artigo 177 da Carta de 1937, Oliveira Vianna ${ }^{23}$ já propunha uma interpretação construtiva no âmbito do Direito Público Constitucional e Administrativo, com critérios mais largos que aqueles utilizados pelo Direito Privado. Ruy Barbosa se empenhava em se fazer compreender na aplicação dos institutos e princípios que haviam sido adotado no Brasil, com a Constituição de 1891. Neste sentido, Ruy não pugnava pela ampliação do poder interpretativo do Direito pelos juízes, mas apenas lhes tentava fazer ver que os paradigmas jurídicos haviam sido alterados com a Constituição Republicana. Diversamente, Oliveira Vianna, propunha método interpretativo do Direito Público, construtivo, o que se opunha ao limitado método de verificação do sentido e alcance da lei, notadamente de seu contemporâneo Carlos Maximiliano ${ }^{24}$.

O Judiciário, no sistema da separação dos poderes instituído nos EUA tivera a previsão de legislador negativo com capacidade de afastar a aplicação da lei e aplicar a Constituição que com ela se incompatibilizava porque " $a$ Constituição deve prevalecer sobre a lei ordinária, a intenção do povo sobre a de seus agentes" (Hamilton, 2005: 472). Mas, com o advento do Estado do bem-estar social o judiciário assumiu o papel de legislador implícito, instituindo políticas públicas, em substituição do papel do legislativo e as implementando, em substituição do executivo.

Assim, as normas programáticas dispostas na Constituição passaram a ser postuladas no tempo das demandas sociais e não mais no tempo dos gestores das decisões políticas. Isto decorre do fato de que o tempo das demandas é diferente do tempo da implementação das políticas. O Judiciário que fazia controle de legalidade dos atos do poder público é demandado para o controle da conveniência e oportunidade do atuar do Estado, substituindo por vezes o pronunciamento que previamente cabia aos gestores das políticas públicas.

\footnotetext{
${ }^{23}$ Vianna, 1991: 150

${ }^{24}$ Carlos Maximiliano, foi Ministro da Justiça do Presidente Wenceslau Brás, e no Governo Vargas, foi Consultor Jurídico do Ministério da Justiça, Consultor-Geral da República, a partir de 1934 foi Procurador-Geral da República e em 1936 foi indicado Ministro do STF. Pela Carta de 1937, que reduziu a idade limite para permanência no STF para 68 anos, foi aposentado; é autor do clássico Hermenêutica e Aplicação do Direito que desde a primeira edição em 1924 até hoje, já mereceu 19 edições e cerca de 25 tiragens.
} 
Neste contexto, torna-se necessário pensar e repensar o aflorar da judicialização da política e, em 318requente318ia, os novos papéis que, no Estado Constitucional e Federativo, os Tribunais e os órgãos do Poder Judiciário vem exercendo. Certos conceitos e noções estruturados pelas ciências sociais possibilitam tal repensar. Entre outros, modernidade, racionalidade, clã e cordialidade. Tais categorias do pensamento podem propiciar, por exemplo, melhor compreender os processos de recrutamento dos membros do Poder Judiciário. No caso porque os mecanismos de recrutamento e ascensão aos postos de direção dos Tribunais podem estar relacionados a expansão das atribuições e uma cada vez maior independência do Poder Judiciário.

O contato do Direito com a Política é permanente, considerando que é a expressão das forças capazes de ditá-lo e executá-lo. No Brasil, o judiciário não só é encarregado de, com exclusividade, aplicar o Direito ${ }^{25}$, mas é, também, um Poder que estabelece a diferença entre os distintos papéis desempenhados pelo Judiciário em nossa organização estatal, pois "No exercício de suas funções, o Judiciário, segundo prescreve a Constituição brasileira, tem duas faces: uma, é poder do Estado; outra, de prestador de serviços”. (Sadek, 2002: 413)

A “judicialização da política”, no Brasil, é um principio que não afasta da apreciação do Poder Judiciário qualquer lesão ou ameaça a direito ${ }^{26}$. Tal princípio não estava contido na Constituição de 1891, mas Ruy Barbosa (1928:284; 2004:105) dizia que nenhum caso poderia ser excluído da apreciação do Poder Judiciário no que se relacionasse com a sua legalidade ou quando praticado de acordo com a lei, mas em contrariedade à Constituição. A Constituição de 1937 trazia dispositivo expresso vedando ao Judiciário analisar casos políticos ${ }^{27}$. Igualmente verificamos fenômeno distinto que é a "judicialização das relações sociais", onde o judiciário tem sido cada vez mais colocado como árbitro das relações que se travam no seio da sociedade. Em artigo sobre a participação através do Direito e judicialização da política, Araújo afirma que a judicialização das relações sociais é fenômeno distinto da judicialização da política.

Mas, o pronunciamento judicial, em matérias políticas, se norteia pelos limites impostos pela Constituição e pelas leis. Não cabe juízo político de conveniência ou

\footnotetext{
25““A lei não excluirá da apreciação do Poder Judiciário lesão ou ameaça a direito.” (Art. $5^{\circ}$, XXXV da Constituição da República).

${ }^{26}$ Constituição de 1988: art. $5^{\circ}$, XXXV, EC/01 1969: art. 153, § $4^{\circ}$ (exceção art. 181), Constituição de 1967: art. 150, § $4^{\circ}$ (exceção art. 173), Constituição de 1946: art. 141, § $4^{\circ}$.

${ }^{27}$ Constituição de 1937: "art. 94. É vedado ao Poder Judiciário conhecer de questões exclusivamente políticas"
} 
oportunidade no pronunciamento, mesmo que a "idéia de justo" do julgador não corresponda à "idéia de justo" do legislador. Mas, os conceitos principiológicos contidos nos dispositivos constitucionais, por suas indeterminações propiciam que os julgadores se fundamentem na ética desejável ante os preceitos ou na 319requent, embora não estejam autorizados a julgar por 319requent ${ }^{28}$. Apesar disto, o "senso de justiça" e o "bom senso" tem levado a decisões fundadas em suposta 319requent, o que implica em usurpação da função legislativa ${ }^{29}$.

No sistema brasileiro, o direito é legislado, teoricamente sob parâmetro racional, e a formação de "idéia de justo", fora dos parâmetros fixados institucionalmente, pode ser tida como expressão do arbítrio ou caprichos do julgador. Tal postura pode implicar em "politização da justiça", favorecimento, autoritarismo ou cordialidade, procedimentos típicos das sociedades tradicionais.

Ferreira Filho comenta que "a judicialização da política ... tende a trazer a politização da justiça" e "antevê a politização da justiça, como 319requente319ia próxima dessa judicialização....”. (Ferreira Filho, 1995: 1) Segundo ele pela judicialização da política é “largamente responsável a Constituição de 1988,", mas, à retração do Welfare state no final do século XX não correspondeu uma retração do Direito e do Poder Judiciário. Ao contrário, na crise do Estado do bem-estar social, que atinge o seu clímax após a queda do Muro de Berlim e a desintegração da União Soviética, o Direito e o Poder Judiciário passaram a ser demandados como novas forças no jogo político na garantia de direitos individuais e sociais exigíveis, bem como na conquista de novos direitos e ampliação do sentido e alcance de políticas em vias de instituição ou implementação.

\section{A Judicialização da Política: Apropriações, Usos e Conceitos}

O termo "judicialização da política" tem sido apropriado e usado para designar fenômenos diversos e em distintas áreas do saber, dentre outras: o direito, a antropologia, a sociologia e a ciência política. Trata-se de uma autêntica "miscelânea" onde o que parece ser comum é a amplitude do significado conceitual que a expressão

\footnotetext{
${ }^{28}$ Dispõe o art. 127 do Código de Processo Civil que "O juiz só decidirá por eqüidade os casos previstos em lei."

${ }^{29}$ O julgamento fora dos parâmetros determinados pelo legislador implica em usurpação da função legislativa, conf. Locke, 1998: 560.
} 
ganha em cada uma destas áreas do conhecimento, bem como, a divergência de sua essência entre as mesmas.

O processo de judicialização da política e das relações sociais, fenômeno tipicamente ocidental, pode ser entendido como produto de três momentos distintos: sua origem nos Estados Unidos, com os federalistas (século XVIII); sua revitalização na Europa do pós-guerra, principalmente através de Hans Kelsen; e na sua incorporação nas Constituições das novas democracias ${ }^{30}$. Cada processo, a sua maneira, obedeceu a uma lógica e parâmetros para a atuação do Poder Judiciário no cenário político. De uma forma ou de outra, o que ficou patente foi a capacidade de veto pelo Judiciário, de intervir em políticas públicas e alterar, em alguns casos, o status quo vigente.

A capacidade do Judiciário de controlar as ações no mundo político tem sido interpretada, por alguns ${ }^{31}$, como tensão da política e, por outros ${ }^{32}$, como dado elementar das democracias contemporâneas.

Como responsáveis pela expansão do Poder Judiciário no Brasil podemos identificar diversos fatores, entre os quais: a lei da ação civil pública em $1985^{33}$; a Lei que instituiu os Juizados de Pequenas Causas em 1984 para questões de pequeno valor econômico e pequena complexidade ${ }^{34}$. Lei posteriormente revogada pela Lei 9099/95 e que instituiu os Juizados Especiais Cíveis e Criminais; o Código de Proteção do Consumidor $^{35}$, que aumentou o tempo para reclamações dos defeitos dos produtos ou serviços e instituiu a possibilidade de inversão do ônus da prova ao fornecedor; o Estatuto da Criança e do Adolescente, ${ }^{36}$ que criou um conjunto de direitos para crianças e adolescentes; a edição de leis de efeitos concretos sobre direitos e garantias (sobretudo as resultantes de planos econômicos); a atribuição de maiores garantias aos magistrados (após os anos em que ocorreram cassações e aposentadorias compulsórias durante a vigência do AI-5); a transição política realizada após os governos militares; a urbanização ocorrida no Brasil nos últimos 60 anos, quando a população rural, que era

\footnotetext{
${ }^{30}$ Maria Tereza Sadek afirma que o desenvolvimento dos Estados Democráticos e suas políticas de bemestar social forçaram mudanças na engenharia institucional e a transformação do Judiciário em um poder ativo. (Sadek, 2002: 413)

${ }^{31}$ Luiz Werneck Vianna aponta uma inevitável tendência ao estabelecimento de uma linha de tensão nas relações entre o Judiciário, de um lado, e o Executivo e o Legislativo de outro. (Vianna, 1999: 10)

${ }^{32}$ Sadek, 2002.

${ }^{33}$ A lei 7347 de 1985 instituiu uma modalidade de ação coletiva, qual seja a ação civil pública.

${ }^{34}$ Lei $7244 / 84$

${ }^{35}$ Lei $8078 / 90$

${ }^{36}$ Lei $8069 / 90$
} 
superior à urbana, reduziu e a urbana multiplicou-se por mais de 10 e A instituição da reparabilidade do dano moral $^{37}$, a partir da Constituição de 1988.

Os fatores arrolados ajudam a compreender porque, nos dias atuais, se dá uma presença 321requente do Poder Judiciário na arbitragem de conflitos que tem na base fenômenos de natureza política, lato senso. Além disto, não se pode desprezar o aumento da demanda pelo Poder Judiciário em razão do processo de urbanização pela qual o país passou nos últimos 60 anos, a exemplo do que ocorre na busca por outros serviços prestados pelo Estado, dentre os quais o serviço de saúde pública e matrícula na rede pública de ensino, demanda por educação em geral, os serviços de iluminação e telefonia, as relações de crédito e outros serviços considerados essenciais numa sociedade urbana. Ao lado disto há também a explicação da expansão da atividade do Poder Judiciário a processos de mudança social e institucional resultante da interação entre os diversos agentes judiciais, políticos e sociais ou ainda pela possibilidade de obtenção de vantagens decorrente das deficiências do aparelho judicial.

Decorrente do maior número de feitos ajuizados e processados nos órgãos do Poder Judiciário no Brasil, o que tem caracterizado um acúmulo de processos em julgamento ou pendentes dele, bem como da maior possibilidade do exercício do poder jurisdicional (seja pela possibilidade jurídica dos pedidos, ante a criação de novos direitos, seja pela maior garantia aos julgadores) as instituições judiciais brasileiras ganharam maior visibilidade na mídia o que tem ensejado um grande debate sobre o seu papel.

Esta maior visibilidade social e exposição na mídia do Poder Judiciário, tem proporcionado discussão sobre o seu papel como poder do Estado. Despertou também o interesse de pesquisadores de diferentes áreas do conhecimento. Para o cientista político Luiz Werneck Vianna a judicialização da política "está na descoberta, por parte da sociedade civil, da obra do legislador constituinte de 1988, e não nos aparelhos institucionais do Poder Judiciário”. (Vianna, 1999: 43).

Neste sentido é possível falar-se que a judicialização está na descoberta do judiciário como capaz de mediar a solução de determinados conflitos e não nos aparelhos legais de existência anterior ou posterior à edição da Carta de 1988.

\footnotetext{
${ }^{37}$ Dano moral é dano de ordem imaterial, consistente num transtorno psíquico ou emocional indevidos; numa perturbação ao sossego, tranqüilidade ou sensação de bem-estar. Com a Constituição de 1988 o dano moral passou a ser inquestionavelmente indenizável, o que gerou o que se chama de "indústria do dano moral".
} 
No âmbito das ciências sociais, sobretudo a partir da última década do século passado, diversos trabalhos ${ }^{38}$ tem sido realizados tendo como tema as relações entre as instituições judiciais e as instituições políticas, o que propiciou a que termos como "judicialização da política", "politização da justiça" e "judicialização das relações sociais" passassem a fazer parte do universo vocabular dos juristas e cientistas sociais.

A expansão do Poder Judiciário não se caracteriza necessariamente pelo que se denomina judicialização da política, traduzido na sua capacidade de arbitrar conflitos que tenham por fundamento relações políticas, assim como não possibilita a compreensão de tais conflitos, pois expressa conceito distinto do termo em análise.

A análise da expansão do Poder Judiciário precisa ser tomada paralelamente aos conceitos onde se possa atribuir a judicialização da política. Isto porque judicialização da política acaba por ser "conceito pouco preciso, mas de rápida aceitação pública" (Maciel e Koerner, 2002), o que pode ser inadequado para compreensão das relações entre o judiciário e a política na democracia brasileira ou, ainda, entre o judiciário e os demais atores sociais. De qualquer forma, é importante ressaltar a imprecisão do conceito de judicialização da política, apropriado e usado em diferentes contextos.

A judicialização das relações sociais, como expressão da crise do poder tradicional e dos seus mecanismos de compor os conflitos de interesse e a expansão do Poder Judiciário determinado pela sua descoberta como agente intermediador na solução de conflitos para os quais antes não era chamado. Tal fato se relaciona com a desregulamentação do Estado, no seu papel de formulador e implementador de políticas públicas, aliado à urbanização verificada na sociedade brasileira nos últimos 60 anos. Esta questão mais ainda se evidencia no momento presente, com as reformas neoliberais e a internacionalização do capital e é neste sentido que observa um estudioso das mídias globais: "No reinado neoliberal, ocorre um processo brutal de desregulamentação, de depreciação do papel do Estado como âmbito de representação pública, de esvaziamento da sociedade civil e enfraquecimento dos laços comunitários." (Moraes, 2004: 193)

Débora Alves Maciel e Andrei Koerner, em estudo sobre o termo judicialização da política, salientam que: "a expressão passou a compor o repertório da ciência social e do direito a partir do projeto de C. N. Tate e T. Vallinder (1996), em que foram

\footnotetext{
${ }^{38}$ Vale ressaltar o trabalho de Marcus Faro de Castro, 1997: 147 para quem "o funcionamento das cortes judiciais e seu papel na democracia têm sido pouco estudado pela Ciência Política brasileira", ao contrário do que afirma Gisele Silva Araújo, op. Cit. Pag. 1, para quem a judicialização da política tem sido objeto freqüente de estudos pelas Ciências Sociais
} 
Q

formuladas linhas de análise comuns para a pesquisa empírica comparada do Poder Judiciário em diferentes países". (Maciel e Koerner, 2002).

No sentido acima considerado os termos judicialização da política ou politização da justiça seriam análogos e expressariam na verdade a expansão do Poder Judiciário e de sua capacidade de proferir julgamentos, envolvendo matérias de natureza política e somente cabíveis nas democracias, onde os juízes gozam de algumas garantias capazes de lhes propiciar o pronunciamento sobre causas políticas, acolhendo ou rejeitando a pretensão das partes. Desta forma, somente onde mecanismos de proteção aos direitos foram editados, possibilitando ações coletivas ou defesa das minorias, bem como atribuição de garantias aos magistrados, teria sentido falar-se em expansão do poder judicial.

Assim, judicializar a política, segundo Tate e Vallinder (Tate e Vallinder, apud Maciel e Koerner: 2002) "é valer-se dos métodos típicos da decisão judicial na resolução de disputas e demandas nas arenas políticas", seja através da ampliação das áreas de atuação dos tribunais mediante a revisão judicial, ou seja, controle de compatibilidade com a constituição das leis, ou atos normativos editados no âmbito da atividade legislativa, pela via de declaração de inconstitucionalidade direta ou incidental, ou ainda pela verificação da legalidade dos atos do executivo. Outro sentido de judicialização da política indicado seria a adoção no legislativo de mecanismo próprios da atividade judicial, como os julgamentos por crimes de responsabilidade que se processam perante o Senado Federal (Brasil: 2004) ${ }^{39}$, cujo procedimento está delineado na Lei de Responsabilidade ${ }^{40}$ (Brasil, 2004), ou ainda pela constituição de Comissões Parlamentares de Inquérito, com poderes próprios das autoridades judiciais.

Diz a Constituição (Brasil: 2004) que compete privativamente ao Senado Federal processar e julgar ${ }^{41}$ o presidente e vice-presidente da República, nos crimes de responsabilidade e os ministros de Estado nos crimes da mesma natureza conexos com aqueles, bem como os ministros do Supremo Tribunal Federal, o procurador-geral da República e o advogado-geral da União, também nos crimes de responsabilidade. Por outro lado diz a Constituição (Brasil: 2004) que as comissões parlamentares de inquérito $^{42}$, terão poderes de investigação próprios das autoridades judiciais, além de

\footnotetext{
${ }^{39}$ art. 52, I e II

${ }^{40}$ Lei 1079/50, publicada no D.O.U. de 12/04/1950 e disponível no site da presidência da república em 14/11/2005, às 02:30h. https://www.planalto.gov.br/

41 art. 52 I e II

art. $58, \S 3^{\circ}$
} 
outros previstos nos regimentos das respectivas Casas do Congresso Nacional, cuja conclusão deve ser encaminhada ao Ministério Público para que promova a responsabilização civil ou penal das pessoas implicadas nos fatos apurados.

Ao dispor sobre poderes de investigação próprios das autoridades judiciais refere-se a Constituição aos poderes próprios das instituições judiciais, dentre as quais a possibilidade de expedir intimações, convocações, quebra de sigilos bancário e telefônico etc... Enfim praticar todos os atos que somente por determinação judicial poderiam ser praticados. Neste sentido o que temos é o legislativo promovendo atividade executiva, com poderes típicos do judiciário, porque as instituições judiciais no Brasil não desenvolvem atividade investigatória. Estas são desempenhadas pelos órgãos da polícia judiciária (que é órgão do executivo) e pelo Ministério Público (que apesar da autonomia que lhe compete em nosso sistema é órgão que desempenha atividade executiva)

Embora tratadas como expressões correlatas a judicialização da política e a politização da justiça exprimem conceitos distintos. Esta expressa, ao contrário, em valer-se o judiciário de métodos típicos das disputas e demandas das arenas políticas para resolução dos conflitos que lhe submetidos e nos quais se espera sejam apreciados com os métodos próprios dos meios judiciais, qual seja, em submissão à legalidade e não aos juízos de conveniência e oportunidade que orientam as ações dos atores políticos. Segundo Maciel e Koerner "se na idéia da política judicializada estão em evidência modelos diferenciais de decisão, a noção de politização da justiça destaca os valores e preferências políticas dos atores judiciais como condição e efeito da expansão do poder das Cortes." (Maciel e Koerner, 2002) Neste sentido, a politização da justiça pode, numa sociedade cordial $^{43}$, implicar na pessoalização da jurisdição.

O termo judicialização da política passou a ser largamente utilizado no final do século XX embora seu emprego venha se dando em diversos sentidos, por vezes contrários. Não raro foi apropriado e empregado com sentido muito genérico. Entretanto, foi apropriado para análise das transformações ocorridas nas relações de grupos ou seus representantes no Poder Judiciário, que ante a inovação da ordem jurídica, antes mesmo da promulgação da Constituição de 1988, já possibilitava que

\footnotetext{
${ }^{43}$ Antônio Cândido em prefácio à $\sigma^{a}$ edição de Raizes do Brasil, intitulado "o significado de 'raizes do Brasil" diz que "O 'homem cordial' não pressupõe bondade, mas somente o predomínio dos comportamentos de aparência afetiva, inclusive suas manifestações externas, não necessariamente sinceras nem profundas, que se opõem aos ritualismos da polidez. O 'homem cordial' é visceralmente inadequado às relações impessoais que decorrem da posição e da função do indivíduo, e não da sua marca pessoal e familiar, das afinidades nascidas na intimidade dos grupos primários.” (Holanda, 195: 17)
} 
grupos políticos minoritários, governos e organizações não-governamentais, utilizassem os mecanismos jurídicos para se contraporem, por vezes, às decisões da maioria ou mesmo pessoas individualmente postularem interesses coletivos ou difusos. Já na Constituição de $1934^{44}$ foi instituída a ação popular ${ }^{45}$ destinada a anulação de atos lesivos ao patrimônio público federal, estadual ou municipal. Tal ação foi mantida na Constituição de $1946^{46}$. A expressão atos lesivos já ampliava o objeto da ação popular, pois além da legalidade, os atos do poder público poderiam ser impugnados pela lesividade.

Comumente, o judiciário vem sendo demandado por atores políticos e sociais na busca da efetivação dos seus interesses não alcançados na arena política ou compostos pela mediação dos mecanismos tradicionais. Analisando o contexto em que se formava uma maioria parlamentar para dar sustentação ao governo FHC, Werneck Vianna analisando a judicialização da política entende que ela define a ação dos tribunais e a ampliação dos mecanismos de proteção das minorias.

Werneck Vianna ${ }^{47}$ utiliza o termo judicialização da política para descrever a utilização dos recursos ao judiciário, ante o que seria uma descoberta da proteção judicial pelas minorias parlamentares, pelos governos estaduais, por organizações nãogovernamentais e a mudança protagonizada nos tribunais que teriam passado a acolhêlas.

A instituição de novos mecanismos, dentre os quais aqueles dispostos nas leis retro mencionadas pode ter propiciado uma maior relevância do Poder Judiciário na solução de conflitos envolvendo atores políticos ou conflitos de interesses entre maioria e minoria, seja social ou parlamentar. Outros mecanismos já existentes passaram a ser largamente utilizados pela sociedade. A ação popular, por exemplo, como já foi anteriormente dito, foi instituída no Brasil pela Constituição de 1934, suprimida na Constituição de 1937, e restabelecida pela Constituição de 1946. Com a edição da Lei 4717 de 1965 ampliou o rol dos entes passíveis de terem seus atos impugnados. A partir de então não só a União, os Estados e Distrito Federal e Municípios podiam ter seus atos impugnados, mas também os entes da administração indireta (autarquias, fundações, sociedades de economia mista e empresas públicas), e os serviços sociais autônomos custeados pelo poder público (SESI, SENAI, SENAC, SESC etc...). Mas, é

\footnotetext{
${ }^{44}$ Campanhole, 1978: 552

45 art. $113, \S 38$,

${ }^{46}$ Campanhole, 1978: 254.

${ }^{47}$ Vianna, 1999: 10
} 
paradoxal que de análise de recursos apreciados pelo Supremo Tribunal Federal (STF, 2005), e constantes no rol de jurisprudência exposta no site daquela Corte, do ano de 1953 a 2004, se verifique que em nenhum outro ano se tenha julgado mais recursos alusivos a ações populares que o ano de 1969. Naquele ano o STF, em plena vigência do AI-5, julgou 9 recursos alusivos a ação popular, número só igualado nos anos de 1997, 2000 e 2001. Em nenhum outro ano de 1953 a 2004 o STF julgou maior número de recursos em ação popular que o ano de 1969. Ferreira Filho ${ }^{48}$ explica o recurso à via judicial para controle dos atos do poder político pelo fato de estar o legislativo "domesticado".

Mas, esta linha de argumentação de Ferreira Filho e outros autores anteriormente citados - no nosso entendimento - não se apresenta convincente. Pois, se o legislativo estava "domesticado" o judiciário estava "acorrentado", após as cassações ${ }^{49}$ e supressão, na prática, das garantias da magistratura.

Esta percepção do Poder Judiciário como estuário das insatisfações com os atos do poder político, não pode ser identificada como novo papel constitucional, pois desde a instituição da separação dos poderes com a Constituição de 1891 ao Poder Judiciário foi atribuída a tarefa de realizar o controle de constitucionalidade das leis. Além disto, as questões de natureza política sempre estiveram sujeitas á revisão judicial, desde que apresentadas sob o ponto de vista da legalidade.

Outro sentido apropriado e utilizado, sobretudo no campo jurídico, do termo judicialização da política o é para expressar a preferência do autor de uma ação pela via judicial, quando poderia pelos mecanismos políticos buscar resolver os conflitos com seus adversários. Neste sentido as disputas eleitorais submetidas à Justiça Eleitoral, sobretudo impugnação de transferência de domicílio eleitoral, de registro de candidato, de diplomação e de mandato, são tratadas como judicialização da política, embora tais casos possam ser tratados com exclusiva fundamentação legal. A expressão é aí empregada pela motivação do autor da ação ou do procedimento, visando atingir, pela via judicial, o adversário político. Neste sentido, embora o vocábulo seja novo, a judicialização da política se faz presente no Brasil desde 1932, quando por força do Decreto 21.076, de 24 de fevereiro de 1932 foi criada a Justiça Eleitoral e submetido ao Poder Judiciário a apreciação de tais questões. Mas, ainda no campo jurídico, os

\footnotetext{
${ }^{48}$ Ferreira Filho, 1995: 5

49 Juízes e Desembargadores de diversos Estados do Brasil foram cassados desde o primeiro ato institucional após o golpe militar de 1964. Três Ministros do Supremo Tribunal Federal foram cassados num só ato em 17/01/1969: Victor Nunes Leal, Hermes de Lima e Evandro Lins e Silva.
} 
tribunais denominam de judicialização da política aquelas ações cujo fundamento tenha natureza política, embora submetidas à apreciação judicial em forma de questão legal. Neste sentido Ruy Barbosa desde a Constituição de 1891 já submetia questões aos tribunais, de interesse político, mas para controle de legalidade.

Ao lado da expressão qualitativa das submetidas e aceitas para processamento nos tribunais, o termo ainda pode ser tratado como expressão do aumento quantitativo de feitos cotidianamente ajuizados, das mais diversas naturezas, o que expressaria uma “judicialização da vida", a judicialização do Estado ou ainda a judicialização do Estado para citar título de obra de André Luis Alves de Melo (Melo, 2001) que é "A judicialização do Estado brasileiro, um caminho antidemocrático e monopolista", implicando a partir da atuação do Ministério Público uma concepção autoritária e paternalista em substituição dos poderes da sociedade pelos poderes do Estado, seus órgãos e seus agentes. Neste sentido o termo mais apropriado seria judicialização das relações sociais, e que será objeto de análise no próximo capítulo, para designar o fenômeno onde "não se encontram mais cidadãos, e sim indivíduos fragilizados $e$ temerosos, que buscam no Judiciário uma saída para os mais banais conflitos cotidianos: são clientes da justiça, reivindicando proteção diante da ameaça constante do outro" (Sierra, 2005).

A falta de precisão terminológica ou a utilização de termos em dimensões próprias em autores de distintas áreas de conhecimento pode propiciar dissonâncias conceituais porque se na ciência política termos como tutela ${ }^{50}$, hipossuficiência ${ }^{51}$, proteção $^{52}$ etc... têm sentido político-ideológico, no campo jurídico têm sentido próprio. Por fim, a utilização do termo judicialização da política para exprimir conceitos distintos em cada estudo, por ser termo de pouca precisão conceitual, pode tolher a adequada formulação de problemas e análises empíricas sobre os mecanismos internos de funcionamento do Poder Judiciário.

\footnotetext{
${ }^{50}$ Tutela não pressupõe a incapacidade da pessoa e não reflete uma concepção de relação paternalista do Estado sobre o indivíduo. Mas, da exclusividade que o Estado reclama em dizer o direito. Daí é que Direito é aquele que o Estado confere tutela.

${ }^{51}$ Hipossuficiência é termo que designa a incapacidade de custeio das despesas de um processo, sem prejuízo do próprio sustento ou da família. Membros da classe média, proprietários de imóvel em região nobre e de carro novo podem ser, ao menos momentaneamente, considerados pobres para efeitos legais, por não disporem naquele dia ou período em que as custas devem ser pagas dinheiro para o pagamento.

52 Diz-se que as relações jurídicas são relações sociais, relevantes para o Direito, o qual lhes atribui proteção. O uso do termo proteção não remete a paternalismo. Mas, garantia de exigibilidade através do Estado, dada a impossibilidade de se fazer justiça com as próprias mãos.
} 


\section{A Judicialização da Política e Judicial Review}

Em 1803 a Suprema Corte norte-americana deparou-se com o caso Marbury versus Madison, onde questões de ordem política e jurídicas se entrecruzaram. Da solução deste caso, pelo juiz John Marshall, resultou o que hoje se denomina "controle de constitucionalidade das leis ou atos normativos" e propicia um dos sentidos do que se denomina judicialização da política.

Os Republicanos, liderados por Thomas Jefferson, derrotaram os Federalistas, liderados por Alexander Hamilton. Antes da passagem do poder em 1801, os Federalistas criaram cargos e fizeram nomeações que os Republicanos não pretendiam manter. Dentre os cargos criados estava o de Juiz de Paz do Distrito de Columbia. O Presidente John Adams havia indicado ao Senado William Marbury, para ocupar o citado cargo. O Senado aprovara a nomeação e fora expedido o termo de investidura. Os nomeados não haviam recebido os termos de investidura e não tinham tomado posse, pois o Secretário de Estado (da gestão do Presidente Adams), John Marshall não as preparara. Igualmente, não promoveu as investiduras nos cargos nomeados o novo Secretário de Estado, James Madison, da gestão do Presidente Jefferson, opositor do governo anterior que havia feito as nomeações ${ }^{53}$.

Na sessão da Corte Suprema de fevereiro de 1803, William Marbury e outros impetraram, contra James Madison, uma ação de mandamus $^{54}$, requerendo a notificação de James Madison, dando ensejo a que fosse julgada - pela primeira vez - uma causa desta natureza ${ }^{55}$. Causa que, na literatura jurídica pertinente, tem sido apontada como tendo dado origem ao fenômeno contemporaneamente designado como judicialização da política.

\footnotetext{
${ }^{53}$ Lobo, Américo. Decisões Constitucionais de Marshall - Presidente do Supremo Tribunal dos Estados Unidos da América. - Imprensa Oficial: Rio de Janeiro, 1903.

${ }^{54}$ Mandamus é expressão utilizada no campo jurídico significando um mandado de garantia de um direito expedido por autoridade judiciária. A ação com preceito mandamental, contendo uma ordem assecuratória de direito foi instituída no Brasil em 1934, quando foi estabelecido o mandado de segurança, ante a desproteção operada pela reforma constitucional de 1926 que restringiu o habeas corpus à defesa da liberdade de locomoção. Originário do Direito Anglo-saxão, o mandamus nos chegou pelos EUA, após a extensão que Ruy Barbosa conseguiu atribuir ao habeas corpus na primeira república e que fora restringido em 1926. Na Argentina o "recurso de amparo" decorreu de uma criação jurisprudencial da Suprema Corte, sendo posteriormente ratificada pela Lei Nacional 16.986, de 20/10/1966 , que instituiu a concessão do "amparo" "contra todo ato ou omissão de autoridade pública que, em forma atual ou iminentemente, lese, restrinja, altere ou ameace, com arbitrariedade ou ilegalidade manifesta, os direitos e garantias, explicita ou implicitamente reconhecidos pela Constituição Nacional, com exceção da liberdade individual tutelada pelo habeas corpus", conforme Baleeiro, 1968: 203.

${ }^{55}$ Lobo, 1903: 1.
} 
John Marshall, ex-secretário de Estado do Presidente Adams, fora nomeado juiz da Suprema Corte e lhe coube o julgamento do mandamus impetrado por Marbury.

O que se celebrizou nesse caso, foi a consolidação em mãos dos juízes do poder de controle de constitucionalidade - the power of judicial review (o poder de revisão judicial) - que reconheceu aos juízes norte-americanos, de modo definitivo, a faculdade de rever perante a Constituição os atos dos legisladores.

$\mathrm{O}$ argumento que o Juiz John Marshall lançou mão foi aquele exposto pelo candidato derrotado à Presidência na Carta ao Povo de Nova York, que resultou no número $78 \mathrm{~d}^{\prime} \mathrm{O}$ Federalista ${ }^{56}$ foi de que as leis são elaboradas pelos representantes do povo e por um poder constituído e que a lei ou ato que disponha de forma diferente da Constituição, elaborada pelo povo, é com ela incompatível e não pode ser aplicada, pois esta tem precedência.

O caso Marbury vs. Madison foi o primeiro momento, que se tem notícia, em que se deixou de aplicar uma lei, sob o fundamento da supremacia da Constituição. Foi a primeira vez em que se julga causa desta natureza e se empreendeu resultado no qual a Suprema Corte dos Estados Unidos reviu um ato legislativo.

No Brasil viemos a conhecer a possibilidade de controle de constitucionalidade das leis a partir da edição do Decreto 848 de 11 de outubro de 1890 cujo preâmbulo dispunha que "O Poder de interpretar as leis envolve necessariamente o direito de verificar se elas são conformes ou não à Constituição, e neste caso cabe-lhe declarar que elas são nulas e sem efeito ..." O controle de constitucionalidade das leis ou atos normativos inexistia no Império, isto porque "a sanção imperial expurgia-as de qualquer vicio." (Nequete, 2000d: 23). Ainda assim somente se fazia o controle nos casos concretos, ou seja, na análise de determinado processo se apreciava se o direito postulado deveria ser resolvido à luz da lei ou se esta contrariava a Constituição, caso em que aquela deveria ser afastada e aplicada a Constituição. Inexistia a ação direta de inconstitucionalidade, ou seja, o reconhecimento de inconstitucionalidade por via direta ou controle in abstrato de lei ou ato normativo.

\footnotetext{
${ }^{56}$ Hamilton, 2005.
} 


\section{Judicialização das Relações Sociais}

O fenômeno da judicialização da política, tratado acima, nos remete ao fenômeno que tem sido denominado de judicialização das relações sociais. Assim, o que se denomina judicialização da política está inserido num contexto maior que é o da judicialização das relações sociais, ou seja, da submissão ao Poder Judiciário de questões outrora resolvidas por outros meios, sobretudo pelo poder tradicional.

Na Europa, onde - em regra - não há divisão de poderes, tal como a concebemos no continente americano, as questões políticas sempre estiveram imunes à apreciação do Poder Judiciário. O mesmo não se pode dizer do Brasil, onde remonta à Constituição de 1891 o princípio de que "a lei não excluirá da apreciação do Poder Judiciário nenhuma ameaça ou lesão a direito", e sobretudo após 1932 quando foi criada a justiça eleitoral, com competência exclusiva para apreciar questões político-eleitorais. Há ainda referência ${ }^{57}$ de que a judicialização das relações sociais e a invasão do direito na vida social tem marcas antigas na sociedade brasileira, sobretudo a partir da institucionalização do corporativismo e das relações de trabalho realizadas pela modernização autoritária ocorrida a partir dos anos de 1930. A mediação estatal ao fixar os limites para o exercício das liberdades, bem como os direitos dos grupos, resultou na jurisdicização das relações sociais, fazendo do direito um mecanismo de aplicação constante.

A judicialização das relações sociais para Antoine Garapon decorre do fato de que o Direito se apresenta como promessa de humanismo. Serve para dizer o que existe de humano nos homens e para lembrar que é proibido compará-los a objeto. E mais, que a justiça é um dizer público comprometido com a sociedade e com as gerações futuras. "Antes mesmo de sua função de autorizar a violência legítima, a justiça é uma palavra, e o julgamento, um dizer público. (...) O direito se apresenta in fine como a promessa de humanismo feita por uns aos outros e garantia pela lei." (Garapon, 2001: 168)

$\mathrm{O}$ enfraquecimento do poder tradicional tem trazido ao Poder Judiciário determinadas questões que antes lhe eram estranhas. Assim, conflitos entre pais e filhos sobre limites a estes impostos, divergência entre o casal sobre questões relevantes para suas vidas, sem que isto implique ruptura da vida conjugal pela separação judicial ou

\footnotetext{
${ }^{57}$ Vianna, 1999: 259.
} 
divórcio, e conflitos de ordem religiosa são questões que, hoje, têm sido trazidas ao

Poder Judiciário e que - nem sempre - está o clássico ${ }^{58}$ juiz imbuído da crença na sua capacidade de se pronunciar sobre as mesmas ${ }^{59}$.

\section{Casos de Judicialização de Relações sociais}

A crise no poder tradicional tem propiciado a judicialização das relações sociais. No Brasil, além da judicialização da política e das relações sociais evidencia-se a pessoalização da jurisdição, que se traduz num especial modo de mediação dos interesses em conflito.

\subsection{Judicialização da Morte I}

Analisamos um caso de filha que propôs ação contra a madrastra porque que não fora avisada do sepultamento do pai ${ }^{60}$.

Não há, por vezes, no direito legislado, e chamado de objetivo no campo jurídico, normas que imponham, taxativamente, determinados comportamentos, mas que a eticidade social o reclama e a parte os postula perante o Poder Judiciário.

As obrigações juridicamente consideradas têm como fontes a lei, o contrato ou a declaração de vontade ao passo que a responsabilidade civil juridicamente exigível, se traduz no dever de reparar os danos causados em decorrência de comportamento lesivo.

\footnotetext{
${ }^{58}$ Atribuímos o termo de "clássico juiz" ao magistrado com menos predisposição de explorar as potencialidades de exercício do poder de julgar, enquadrando-se num tipo tradicional de integração da relação jurídico-processual, na qual figura propriamente como terceiro diante do conflito de interesses apresentado pelas partes.

${ }^{59}$ É o que se viu no julgamento do processo 2005.002.003424-4 (TJ/RJ) em que um juiz reclamou na justiça o direito de ser tratado com urbanidade pelos empregados do condomínio onde mora. A imprensa relatou o caso, como se o juiz quisesse ser chamado de excelência e o juiz que julgou a causa disse que aquilo era conflito de natureza social e não comportava pronunciamento judicial. Tal como na "objeção do caso político" de que falava Ruy Barbosa, o juiz da causa deixou de assumir o papel que lhe competia; deixou de se pronunciar sobre o cerne do conflito, traduzido no direito ou não ao tratamento com urbanidade nas relações sociais, certamente por não crer na sua capacidade legal de resolver, ao menos formalmente e no âmbito do processo, conflitos de relação social. Da sentença o juiz fez constar que "Ao judiciário não compete decidir sobre a relação de educação, etiqueta, cortesia ou coisas do gênero, a ser estabelecida entre o empregado e o condomínio e o condômino, posto que isso é tema interna corpore daquela própria comunidade." Do raciocínio do juiz, certamente temeroso da reação da mídia, se depreende que o Estado não é o poder soberano da nação e que não existe entre nós o princípio da inafastabilidade da jurisdição de aplicação pelo Poder Judiciário e reconheceu, nas entrelinhas, a possibilidade de um direito resultante de regulação privada.

${ }^{60}$ Processo 2002.038.017689-4 - $7^{\text {a }}$ Vara Cível de Nova Iguaçu/RJ.
} 
Este último fundamento para a responsabilização civil é que se traduz na porta de entrada de todos quantos queiram, através do judiciário, “juridificar” uma relação. Isto porque mesmo o exercício de um direito pode ser considerado abusivo, desde que irregular. Tanto os pensadores do Direito ${ }^{61}$, quanto o novo Código Civil ${ }^{62}$ admitem a possibilidade de responsabilização de quem tenha exercitado direito sem o proveito necessário.

Aguiar Dias ${ }^{63}$ nos remete à colisão de direitos, tratados como interesses protegidos pelo Estado, e sem explicitar a forma de resolução nos indica a ponderação do interesse para solução do conflito entre direitos.

Da equivalência entre o direito de uns, por utilidade ou necessidade, e o direito de outros, pelas mesmas razões, se busca saber se houve violação injustificada de qualquer deles. Isto porque, não há exercício de direito sem violação de interesses de outros.

Segundo Antoine Garapon "as vítimas de um incesto mais que a condenação do réu, querem ouvir da boca da instituição que foram injustiçadas" (Garapon, 2001: 167). Este tem sido o novo papel do Poder Judiciário, quando tem sido provocado a se pronunciar na ruptura das relações tradicionais que sustentavam as relações familiares no Brasil. E isto porque "a história da justiça é aquela da profanação progressiva de toda autoridade tradicional" (Garapon, 2001: 141).

As partes em determinados processos, mais que uma indenização, reclamam o reconhecimento de que tinham o direito. Mais que indenização reclamam a condenação do comportamento do réu.

$\mathrm{Na}$ inexistência ou diante do enfraquecimento de instituições fundadas no poder tradicional que possam se pronunciar, resta a busca do pronunciamento junto ao Poder Judiciário. Mas “a justiça não é vingança, nem terapia, mas triangulação das relações sociais" (Garapon, 2001: 118). Cabe ao judiciário estar situado no seu papel e a ele se limitar e "Estar situado é estar integrado em uma ordem simbólica; portanto, estar limitado" (Garapon, 2001: 79). Daí é que deve se reservar no seu papel, prestando a jurisdição exigida por meio de ação, dizendo o direito a quem o exige.

\footnotetext{
${ }^{61}$ Miguel Maria de Serpa Lopes, por exemplo, 1989:464.

${ }^{62}$ Código Civil de 2002, art. 187.

${ }^{63}$ Aguiar Dias, 1944: 70
} 
Assim, a ação da filha contra a madrasta que não lhe comunicara o falecimento e sepultamento do pai, tem cabimento em sede judicial. Mesmo diante da existência de preceitos alusivos abstratamente ao caso, não se pode negar aos filhos o direito subjetivo de velarem e sepultarem os pais e que tal direito se revela necessidade de ordem simbólica, com profundas repercussões na esfera psicológica dos agentes envolvidos. O familiar que promove o sepultamento, mas omite deliberadamente, e sem justo motivo, a comunicação de falecimento aos filhos viola tal direito. Igualmente há que se concluir que o mal-estar propiciado pela omissão na comunicação do falecimento e sepultamento do pai se traduz em dano ao filho que se ignorou propositadamente.

Este é um caso em que princípio constitucional pode ser invocado para amparar a causa proposta. É caso típico onde se pode invocar o princípio da dignidade humana, disposto na Constituição como fundamento da República.

A filha, no caso analisado, buscava um ressarcimento do dano moral the imposto. Mas, mais que uma indenização, reclamou o reconhecimento de que tinha o direito de velar e sepultar seu pai. Mais que indenização reclamou a condenação do comportamento da madrasta. A parte autora era assistida pela Defensoria Pública.

\subsection{Judicialização da Morte II}

A incompletude da obra de Gilberto Freyre nos deixa o vazio do estudo dos rituais de sepultamento no Brasil. A obra chegou a ser anunciada em 1959 quando do lançamento de Ordem e Progresso, onde se lê que "Todos esses volumes aparecerão sob a denominação geral de Introdução à História da sociedade Patriarcal no Brasil" (Freyre: 1959, introdução e prefácio). Pretendia Gilberto Freyre que a obra apresentasse um estudo de ritos patriarcais, de sepultamentos e da influência de mortos sobre vivos, com enfoque nas fases de desenvolvimento e desintegração na qual ainda se encontrava a sociedade brasileira, desde o patriarcado até o momento em que escrevia aquela obra (década de 50 do século XX), refletidos nos enterros, covas ou jazigos familiares.

A incompletude da obra de Freyre sobre jazigos e covas rasas não nos impede de analisar o patrimonialismo nos municípios da Baixada Fluminense, onde os serviços funerários foram concedidos a particulares, que exploram economicamente a morte. 
A delegação a particulares da exploração dos serviços de administração dos cemitérios municipais ${ }^{64}$, dos sepultamentos, de traslado dos corpos e de venda de produtos funerários se traduz numa reserva de mercado e viola os princípios apregoados à livre iniciativa da economia capitalista.

Segundo contrato celebrado com empresa funerária de Nova Iguaçu somente esta pode exercitar a atividade funerária naquele município, compreendendo a administração dos cemitérios públicos, a venda de materiais utilizados em sepultamentos, bem como o traslado do corpo dentro ou para fora do município.

A grave questão da saúde pública nos municípios da baixada fluminense leva moradores da região à busca de tratamento no Hospital Geral da Posse, sob administração do Município de Nova Iguaçu, que tem a gestão plena do Sistema Único de Saúde/SUS no âmbito local. A morte de algumas dessas pessoas propiciava o entrave da remoção do cadáver para o município de origem, o que é obstado pela municipalidade e pela funerária local, ávida de receber pelo traslado. Mesmo quando disponibilizado serviço de remoção oriundo de funerária de outra localidade, o corpo não era liberado, ante a exigência de pagamento das verbas funerárias que seriam devidas, se o serviço fosse prestado nos cemitérios situados no próprio município.

A judicialização da morte no município de Nova Iguaçu levou diariamente a propositura de ações visando a liberação de corpos para remoção e sepultamento nos municípios vizinhos, origem do defunto ${ }^{65}$.

A questão nos remete ao patrimonialismo, onde o poder público é o agente provocador da busca da jurisdição e nos remete à crise de legitimidade do Estado. Segundo Paul Ricoeur (apud Garapon, 2001: 14) "Para explicar o que aparece, primeiramente, como uma inflação do judiciário é preciso recorrer às causas da crise de legitimidade do Estado. E reportar-se à esfera do próprio imaginário democrático, no íntimo da consciência do cidadão, onde a autoridade da instituição política é reconhecida." (Ricoeur apud Garapon, 2001: 14)

$\mathrm{Na}$ maioria dos casos julgados pela $7^{\mathrm{a}}$ Vara Cível de Nova Iguaçu nos anos de 2003 a $2005(98,04 \%)$ os requerimentos foram feitos pela Defensoria Pública e somente em $1,96 \%$ o requerente tinha advogado privado, ainda assim sob o patrocínio da

\footnotetext{
${ }^{64}$ Por meio de contrato de concessão celebrado entre o Município de Nova Iguaçu e particular os serviços funerários foram entregues ao monopólio privado, em 12/03/1975 por 20 anos. Tal contrato foi renovado por mais 20 anos em 20/05/1996.

${ }^{65} \mathrm{Em}$ 07/04/2005 foi editado Decreto pelo Prefeito Municipal, Dec. 7.101/2005, que veda à concessionária monopolista dos serviços funerários a cobrança de taxa para permitir retorno do falecido à origem e a retenção do corpo até o pagamento.
} 
gratuidade de justiça, o que evidencia o quanto a Defensoria Pública é um instrumento fundamental no acesso ao Poder Judiciário ${ }^{66}$.

\section{A expansão do Poder Judiciário e a Urbanização da População Brasileira}

Se a expansão do Poder Judiciário no Brasil tem como fatores a urbanização ocorrida na sociedade brasileira nos últimos 80 anos do Século $\mathrm{XX}$, esta não pode ser considerada o único fator.

Dados estatísticos do IBGE e da Fundação CIDE, por situação do domicílio, permite constatar uma perda populacional rural, tanto no Estado do Rio de Janeiro quanto no Brasil, a contar de 1940, ano a partir do qual a variável "situação domiciliar" foi inserida nas pesquisas. A população rural em 2003 era - em números absolutos menor do que era em 1940.

A população rural brasileira reduziu de 1940 até o ano de 2003, ano até o qual foi por nos analisada. Em 1940 a população brasileira era de 41236315 habitantes, sendo 28.356.133 moradores rurais e 12.880.182 moradores urbanos. O IBGE não dispõe de informações sobre a situação do domicílio de anos anteriores a 1940, quando o êxodo rural já se fazia presente, notadamente na década de 30 , com o processo de industrialização. Em 2003 a população brasileira era de 173.966.052 habitantes, sendo 27.286.300 de moradores rurais e 146.679.752 de moradores urbanos. O que se verifica é um refluxo da população rural no Brasil no período de 63 anos analisados.

A diminuição da população rural no Estado do Rio de Janeiro, que se apresenta acentuada, decorre do êxodo rural, mas também decorre do critério para classificação de uma área como urbana ou rural. Assim, a partir de 1940, áreas que eram consideradas rurais passaram a ser classificadas como urbanas. É o que se verifica, sobretudo, no entorno do Recôncavo da Baía da Guanabara.

Entende-se como zona urbana a definida em lei municipal, observando-se como requisito para tal classificação a existência de, no mínimo, dois dos seguintes serviços instituídos ou mantidos pelo Poder Público: meio-fio ou calçamento, canalização de

\footnotetext{
${ }^{66}$ Sobre a essencialidade da Defensoria Pública no acesso ao judiciário veja MORAES, 1996.
} 
Quaestio Iuris

vol.05, $\mathrm{n}^{\circ}$ 01. ISSN 1516-0351

águas pluviais; abastecimento de água; sistema de esgotos sanitários; rede de iluminação pública, com ou sem posteamento para distribuição domiciliar; escola primária ou posto de saúde a uma distância máxima de 3 (três) quilômetros do imóvel considerado. A existência de dois dos serviços acima indicados possibilita a classificação de uma área como urbana ${ }^{67}$.

Conforme se vislumbra da tabela abaixo a população do Estado do Rio de Janeiro em 1940 era de 3.611.998 habitantes, sendo 1.399.787 de moradores rurais e 2.212.211 de moradores urbanos.

Além disto, o município, a quem compete classificar a área como urbana ou rural, pode considerar urbanas as áreas urbanizáveis, ou de expansão urbana, constantes de loteamentos tão somente aprovados, destinados no futuro à habitação, à indústria ou ao comércio, mesmo que localizados fora das zonas definidas nos termos do parágrafo anterior.

O crescimento populacional no Estado do Rio de Janeiro tem sido acompanhado proporcionalmente pelo número de feitos distribuídos no Estado, no período de 1998 a 2004. Igualmente nas comarcas de entrância especial, conforme se vê nas tabelas seguintes, cujos dados foram apurados junto à Fundação CIDE. O índice de crescimento populacional não difere do índice de distribuição de processos na justiça fluminense.

Tal conclusão decorreu de comparação informações relativas à população e distribuição processual, por comarca de entrância especial, com a inclusão e exclusão dos processos de dívida ativa ajuizados pelo poder público.

Nas nove comarcas de entrância especial do Estado do Rio de Janeiro o aumento populacional, em todas elas ocorrido, é proporcional ao aumento do número de distribuição processual. Não há, portando, aumento de demanda judicial incompatível com o aumento populacional.

O que se constatou, também, é que o poder público é, em parte, responsável pelo aumento do número de feitos distribuídos à justiça. A análise do número de feitos distribuídos no período de 1998 a 2004 revela que, excetuados os feitos ajuizados pelo poder público visando cobrança de débitos (nos cartórios da dívida ativa) o ajuizamento de feitos se faz com certa linearidade proporcional e compatível com o aumento populacional. Diversamente, quando se verifica uma discrepância na distribuição de

\footnotetext{
${ }^{67}$ Tais critérios estão determinados no Código Tributário Nacional, que estabelece critérios para diferenciação de área rural e urbana sobretudo em decorrência da cobrança de impostos, quais sejam, IPTU e ITR respectivamente, de competência dos municípios e da União.
} 
processos, eles decorrem de aumento de ajuizamento de processos pelo poder público no ano em que ocorre tais acentuações da distribuição.

É de se ressaltar que a acentuada distribuição processual efetuada por alguns dos municípios se deu em ano eleitoral. O mecanismo da acumulação de processos e distribuição no último ano de mandato, após a eleição, quando o prefeito não se reelege ou não concorre à reeleição é uma constante na nossa realidade. As discrepâncias verificadas na distribuição decorrentes dos ajuizamentos de ações pelas municipalidades ocorrem em anos eleitorais. Mas, não verificamos, se, nos municípios em que tais fatos ocorreram, os prefeitos não concorreram à eleição ou a perderam; tampouco analisamos se os ajuizamentos das ações foram feitos após as eleições. De qualquer forma houve concentração de processos, em alguns dos municípios estudados, para ajuizamento conjunto em um ano, ao passo que em outros municípios se o ajuizamento foi feito paulatinamente ano a ano. Em ambos os casos, os prefeitos estão obrigados ao ajuizamento da ação, até o fim do mandato, para fugir da responsabilização determinada pela lei de responsabilidade fiscal.

As Comarcas analisadas foram as de entrância especial, na seguinte ordem: Rio de Janeiro/Capital, Campos, Duque de Caxias, Niterói, Nova Iguaçu, Petrópolis, São Gonçalo, São João de Meriti e Volta Redonda:

Mas, em cinco municípios do Estado do Rio de Janeiro se aferiu perda populacional, o que não indicou redução proporcional do numero de processos. Ao contrário, apesar da redução populacional, a escala de distribuição processual continuou ascendente, o que afastou hipótese formulada de que o aumento da distribuição de processos decorria do aumento populacional e poderia indicar a inexistência de uma judicialização das relações sociais.

Tem-se assim que se o aumento populacional pode implicar no aumento da distribuição processual, há outros fatores que determinam a judicialização das relações sociais, que não somente o aumento populacional. É o que se verifica nos cinco municípios fluminenses que tivera perda populacional. São eles: Nilópolis, Cambuci, Italva, Santa Maria Madalena e Trajano de Moraes.

No período de 1998 a 2004 o Município de Trajano de Morais registrou uma média de distribuição de cinco processos de dívida ativa por ano, o que suscita as hipóteses de ausência de inadimplência dos tributos municipais, ausência de burocracia institucionalizada para cobrança dos créditos da fazenda municipal ou prevalência de interesses locais capazes de impedir a ação da municipalidade para a cobrança dos 
Quaestio Iuris

vol.05, $\mathrm{n}^{\mathrm{o}}$ 01. ISSN 1516-0351

créditos da dívida ativa. Nos Municípios de Nilópolis, Cambuci, Italva e Santa Maria Madalena, a distribuição de feitos da dívida ativa igualmente não se revela relevante, o que suscita as mesmas hipóteses. 


\section{Referências}

ABREU, Hugo. O outro lado do poder. Rio de Janeiro: Editora Nova Fronteira, 1979.

ARAÚJO, Gisele Silva. Participação através do direito: a judicialização da política. 2004. [Internet] http://www.ces.uc.pt/lab2004/pdfs/GiseleSilvaAraujo.pdf disponível em 03/01/2010 às 19:518h.

ARAÚJO, Gisele Silva. Judicialização da política e das relações sociais: distinção conceitual e democracia. Revista Dados, IUPERJ/UCAM, no prelo.

ASSIS, Machado de. Obras completas, A semana I. São Paulo: Editora Globo, 1997.

BALEEIRO, Aliomar. O Supremo Tribunal Federal, esse outro desconhecido. $1^{\text {a }}$. ed. Rio de Janeiro: Forense, 1968.

BARBOSA, Rui. Atos inconstitucionais. Campinas: Russell, 2004.

, Ruy. Collectanea jurídica. São Paulo: Companhia Editora Nacional, 1928.

, Ruy. O Supremo Tribunal Federal na Constituição brasileira. discurso proferido no Instituto dos Advogados ao tomar posse do cargo de presidente em 19/11/1914. in NUNES, Reginaldo. As Conferências de Haia: O que significaram para o Brasil e para o Direito Internacional. Rio de Janeiro: Forense, s/d.

BRASIL [Constituição ((1988)]. Constituição da República Federativa do Brasil/org. Cláudio Brandão de Oliveira. - $7^{\mathrm{a}}$ ed. - Rio de Janeiro: Roma Victor, 2005.

CAMPANHOLE, Adriano. CAMPANHOLE, Hilton Lobo. Todas as Constituições do Brasil. São Paulo: Atlas, 1978.

CASTRO, Marcus Faro. O Supremo Tribunal Federal e a judicialização da política. in Revista Brasileira de Ciências Sociais. Vol. 12 - n 34. São Paulo: ANPOCS, 1997.

DAMASCENO, João Batista. Mensalão, financiamento de campanha e reforma política. Boletim da Associação Juízes para a Democracia. Ano 9 - n ${ }^{0}$ 34. São Paulo: AJD, 2005.

João Batista. Coronelismo, Urna eletrônica e voto: A Abin e o regime

democrático no Brasil. $\quad$ set-out/2002. [Internet]
http://www.achegas.net/numero/um/j_damasceno.htm disponível em 03/01/2010 às $19: 48 \mathrm{~h}$

DIAS, José de Aguiar. Da responsabilidade civil; vol. I - Rio de Janeiro: Forense, 1944. 
FERREIRA FILHO, Manoel Gonçalves. Poder Judiciário na Constituição de 1988: judicialização da política e politização da justiça. Revista Jurídica 1/21-42. São Paulo: Procuradoria Geral do Município de São Paulo, 1995.

FREYRE, Gilberto. Ordem e Progresso. Rio de Janeiro: Livraria José Olympio Editora, 1959.

GARAPON, Antoine. O Juiz e a democracia: o guardião das promessas. $2^{\mathrm{a}}$. ed. Rio de Janeiro: Revan, 2001.

HAMILTON, Alexander. (et. al.) O federalista. traduzido por Ricardo Rodrigues Gama; $2^{\mathrm{a}}$ ed. - Campinas: Russel Editores, 2005.

JORNAL DO COMÉRCIO. Rio de Janeiro: 12/04/1945.

JUNQUEIRA, Botelho Luciana et al. Juízes retrato em preto e branco. Rio de Janeiro: LetraCapital, 1997.

KOERNER, Andrei. Judiciário e cidadania na constituição da república brasileira. São Paulo: Editora Hucitec, 1998.

LEAL, Victor Nunes. Coronelismo, enxada e voto o município e o regime representativo no Brasil. Rio de Janeiro: Nova Fronteira, 1997.

LOBO, Américo. Decisões Constitucionais de Marshall - Presidente do Supremo Tribunal dos Estados Unidos da América. - Imprensa Oficial: Rio de Janeiro, 1903.

MACIEL, Débora Alves e KOERNER, Andrei. Sentidos da judicialização da política: duas análises. 2002. [Internet]__ http://www.scielo.br/scielo.php?pid=S010264452002000200006\&script=sci_arttext\&tlng=pt disponível em 03/01/2010 às 19:39h.

MACCALÓZ, SALETE. O Poder Judiciário, os meios de comunicação e opinião pública. Rio de Janeiro: Lumen Juris, 2002.

MANGABEIRA, João. Rui, o Estadista da República. Rio de Janeiro: Livraria José Olympio Editora, 1943.

MELO, André Luís Alves de. A judicialização do Estado brasileiro, um caminho antidemocrático $\quad e \quad$ monopolista, ago/2001. [Internet] http://jus2.uol.com.br/doutrina/texto.asp?id=2408, disponível em 03/01/2010 às 19:46h.

MONTESQUIEU, Charles de Secondat, Baron de. O Espírito das leis. São Paulo: Martins Fontes, 1993.

MORAES, Denis de. “O capital da mídia na lógica da globalização". in Moraes, Denis de (Org.). Por uma Outra Comunicação - Mídia, Mundialização Cultural e Poder. Rio de Janeiro: Record, 2004.

MORAES, Humberto Peña de. Democratização do acesso à justiça. assistência jurídica e Defensoria Pública. in Justiça: Promessa e Realidade - O Acesso à justiça em países 
ibero-americanos/organização Associação dos Magistrados Brasileiros, AMB. Rio de Janeiro: Nova Fronteira, 1996.

MUNICÍPIO DE NOVA IGUAÇU. PREFEITURA MUNICIPAL DE NOVA IGUAÇU. Decreto 7.101 de 07/04/2005. Nova Iguaçu: Prefeitura, 2005.

NEQUETE, Lenine. O Poder Judiciário no Brasil: crônica dos tempos coloniais. Colônia. Vol I/Tomo I - Brasília: Supremo Tribunal Federal, 2000a.

, Lenine. O Poder Judiciário no Brasil: crônica dos tempos coloniais.

Colônia. Vol I/Tomo II - Brasília: Supremo Tribunal Federal, 2000 b.

, Lenine. O Poder Judiciário no Brasil a partir da independência - Império.

Vol II/Tomo I - Brasília: Supremo Tribunal Federal, 2000c.

Lenine. O Poder Judiciário no Brasil a partir da independência República. Vol II/Tomo I - Brasília: Supremo Tribunal Federal, 2000d.

ROCHA, Lincoln Magalhães da. A constituição americana: dois séculos de direito comparado. Rio de Janeiro: Edições Trabalhistas, 1990.

RODRIGUES, Lêda Boechat. História do Supremo Tribunal Federal (1930-1963). Tomo IV - Vol. 1. Rio de Janeiro: Civilização Brasileira, 2002.

, Lêda Boechat. História do Supremo Tribunal Federal: Defesa do Federalismo (1899-1910). Tomo II - Tomo I. Rio de Janeiro: Civilização Brasileira, 2002.

Lêda Boechat. História do Supremo Tribunal Federal: Defesa das Liberdades Civis (1891-1898). Vol. 1. Rio de Janeiro: Civilização Brasileira, 1965.

RUY, Barbosa. Collectanea jurídica. São Paulo: Companhia Editora Nacional, 1928.

SADEK, Maria Tereza. Poder Judiciário: críticas e desafios. in Direito e Mudança Social. (org.) DORA, Denise Dourado. Rio de Janeiro: Renovar: Fundação Ford, 2002.

, Maria Tereza. Acesso à justiça. São Paulo: Fundação Konrad Adenauer, 2001.

2001. , Maria Tereza. Reforma do judiciário. São Paulo: Fundação Konrad Adenauer, , Maria Tereza. A justiça eleitoral e consolidação da democracia no Brasil. São Paulo: Fundação Konrad Adenauer, 1995.

SERPA LOPES, Miguel Maria. Curso de direito civil. Vol I, $7^{\mathrm{a}}$. ed. Ver. e Atual. Rio de Janeiro: Livraria Freitas Bastos, 1989.

SIERRA, Vânia Moralez. Crise das representações e o déficit de urbanidade. julago/2004. (internet) http://www.achegas.net/numero/vinteequatro/vania_sierra_24.htm, disponível em 03/01/2010 às 21:53h. 
SILVA, José Afonso. Curso de direito constitucional positivo. $7^{\mathrm{a}}$ Ed. rev. e ampl. de acordo com a nova Constituição. - São Paulo: Editora RT, 1991.

TATE, C. Neal and VALLINDER, Torbjörn, The global expansion of judicial power. New York University Press, New York and London, 1997.

VALE, Osvaldo Trigueiro. O Supremo Tribunal Federal e a instabildiade políticoinstitucional. Rio de Janeiro: Civilização Brasileira, 1976.

VELlOSO, Carlos Mário da Silva. in Nequete, Lenine. O Poder Judiciário no Brasil: crônica dos tempos coloniais - Colônia. Vol I/Tomo I - Brasília: Supremo Tribunal Federal, 2000a.

VELLOSO, Carlos Mário da Silva. in Nequete, Lenine. O poder judiciário no Brasil a partir da independência - República. Vol. II/tomo I - Brasília: Supremo Tribunal Federal, 2000d.

VIANNA. Luiz Werneck, (org.) A democracia e os três poderes no Brasil. Belo Horizonte: Editora UFMG, Rio de Janeiro: IUPERJ/FAPERJ, 2002.

Luiz Werneck, et. al. A judicialização da política e das relações sociais no Brasil. Rio de Janeiro: Editora Revan, 1999.

. Luiz Werneck, et. al. O perfil do magistrado brasileiro. Rio de Janeiro: AMB: IUPERJ, 1996.

VIANNA, Oliveira. Ensaios inéditos. Campinas: Editora da UNICAMP, 1991.

Oliveira. Populações meridionais do Brasil: populações rurais do centrosul. Belo Horizonte: Itatiaia; Niterói: Editora da Universidade Federal Fluminense, $1987 \mathrm{a}$.

, Oliveira. Populações meridionais do Brasil: o campeador Rio-grandense. Belo Horizonte: Itatiaia; Niterói: Editora da Universidade Federal Fluminense, 1987b.

, Oliveira. Instituições políticas brasileiras. Vol. I Rio de Janeiro: José Olympio Editora, 1949.

Nacional. 1939.

Oliveira. O Idealismo na constituição. Rio de Janeiro: Companhia Editora 